DOI: https://doi.org/10.47405/mjssh.v6i9.1024

\begin{tabular}{|c|c|}
\hline & Malaysian Journal of Social Sciences and Humanities (MJSSH) \\
\hline Malaysian Journal of & Volume 6, Issue 9, September 2021 \\
\hline (Mulssh) & e-ISSN : 2504-8562 \\
\hline & $\begin{array}{l}\text { Journal home page: } \\
\text { www.msocialsciences.com }\end{array}$ \\
\hline
\end{tabular}

\title{
Kesedaran Pegawai dan Anggota Polis Diraja Malaysia Tentang Integriti dalam Penyampaian Perkhidmatan
}

\author{
Malike Brahim¹, Mohd Mahiri Hussin², Marwan Ismail ${ }^{3}$, Musliza Mohamad ${ }^{4}$ \\ 1Pusat Pengajian Kerajaan Universiti Utara Malaysia (UUM), 06010 Sintok, Kedah, Malaysia \\ 2Bahagian Pencegahan Jenayah dan Keselamatan Komuniti, Ibu Pejabat Polis Daerah Ipoh, 30000 Ipoh, Perak, Malaysia \\ 3Fakulti Pengajian Bahasa dan Pembangunan Manusia, Universiti Malaysia Kelantan (UMK), 16300 Bachok, Kelantan, \\ Malaysia \\ 4Jabatan Perdagangan, Politeknik Sultan Abdul Halim Mu'adzam Shah, 06000 Jitra, Kedah, Malaysia
}

Correspondence: Malike Brahim (malike@uum.edu.my)

\begin{abstract}
Abstrak
Artikel ini bertujuan membincangkan pemahaman tentang integriti melibatkan pegawai dan anggota dalam pasukan Polis Diraja Malaysia (PDRM). Banyak kejadian yang melibatkan pegawai dan anggota PDRM telah menjejaskan persepsi orang ramai mengenai pasukan keselamatan ini. Objektif kajian ini dijalankan untuk mengetahui pemahaman pegawai dan anggota PDRM tentang usaha memperkukuh integriti; mengkaji semula langkah PDRM untuk memperkasa sumber manusia dan arah kerja berpasukan untuk pembentukan etika dan integriti yang lebih tinggi; menilai kesedaran pegawai dan anggota PDRM mengenai langkah-langkah ke arah memperkukuh integriti dalam organisasi PDRM. Soal selidik yang diolah menggunakan Google Form yang diedarkan melalui WhatsApp untuk mendapatkan input daripada responden. Sampel dipilih menggunakan persampelan rawak berstrata melibatkan pegawai dan anggota PDRM dari Ibu Pejabat Polis Daerah Ipoh dan Ibu Pejabat Kontinjen Perak. Dapatan kajian menunjukkan tahap kesedaran dan pemahaman responden terhadap faktor integriti adalah kuat. Analisis menunjukkan bahawa pegawai dan anggota PDRM menyedari peri pentingnya memupuk integriti dalam penyampaian perkhidmatan polis kepada orang ramai, terutama setelah tiga panduan utama iaitu Kod Etika PDRM, Pelan Integriti PDRM 2016-2020, dan Manual Pematuhan Standard diperkenalkan. Hasilnya, pasukan PDRM harus terus komited untuk meningkatkan integriti untuk mencapai prestasi cemerlang organisasi sebagai agensi keselamatan utama di Malaysia.
\end{abstract}

Kata kunci: integriti, kesedaran, perkhidmatan kepolisan, Polis Diraja Malaysia

\section{Integrity Awareness among the Officers and Staff of the Royal Malaysian Police in Policing Service Delivery}

\begin{abstract}
This essay aims to discuss the level of understanding of police integrity among RMP officers and staff. Numerous incidents involving RMP officers and staff have harmed the public's perception of the security forces. The goal of this study was to determine RMP officers' and staff's understanding of efforts to strengthen integrity; review the RMP's steps to empower human resources and the direction of teamwork for the formation of higher ethics and integrity; assess RMP officers' and staff's awareness of measures to strengthen integrity in the RMP organization. A questionnaire created with
\end{abstract}


Google Form was circulated over WhatsApp to acquire respondent's input, and the sample was chosen using stratified random selection involving RMP officers and staff from Ipoh Contingent Headquarters and Perak Contingent Headquarters. The findings depicted that respondents' mean level of awareness and understanding on factors of integrity is strong. The results of this study show that RMP officers and staff are aware of the importance of cultivating integrity in the delivery of police services to the public, especially after the three main components, the RMP Code of Ethics, the RMP Integrity Plan 2016-2020, and the Standards Compliance Manual, were introduced. As a result, the RMP team must remain fully committed to enhancing integrity to achieve the organization's outstanding performance as a premier security agency in Malaysia.

Keywords: awareness, integrity, Royal Malaysia Police, policing servicing

\section{Pengenalan}

Perbincangan mengenai integriti melibatkan agensi-agensi penguatkuasaan dan keselamatan di Malaysia sejak kebelakangan ini semakin mendapat perhatian umum. Bagi pasukan Polis Diraja Malaysia (PDRM), begitu banyak rungutan, aduan, kritikan dan rasa tidak berpuas hati tentang kecekapan dan keberkesanan mereka dalam menyelesaikan banyak masalah awam. Kualiti dan tahap pelaksanaan tugas dan penyampaian perkhidmatan melibatkan pegawai dan anggota PDRM dilihat tidak cekap dan kurang berkesan. Bila timbul isu seperti ini, ia pasti memberi kesan kepada imej dan kredibiliti pasukan PDRM.

Oleh itu, bukan hal yang asing apabila integriti pegawai dan anggota polis dalam penyampaian perkhidmatan kepolisan kepada rakyat semakin dipertikai. Hal ini kerana, kepercayaan awam terhadap integriti dan akauntabiliti kepada agensi kerajaan mula menurun (Heywood, Marquette, Peiffer \& Zuniga, 2017). Segalanya berpunca daripada gejala negatif dalam proses penyampaian perkhidmatan dan kesannya mula melonggarkan nilai integriti. Justeru, rakyat mula mempertikai keupayaan agensi keselamatan seperti PDRM apabila berlakunya banyak masalah seperti salah laku, penyalahgunaan kuasa, penyelewengan, rasuah, bertangguh dalam menyelesaikan tugas, pilih kasih dan sebagainya. Isuisu ini berpanjangan dalam perkhidmatan kepolisan, di mana jika tidak dibendung boleh menjadi "duri dalam daging" yang merosakkan integriti PDRM.

Dalam menangani isu-isu itu, pada asasnya PDRM sudah ada program khusus untuk meningkatkan integriti. Begitu juga di peringkat kerajaan, apabila bekas Perdana Menteri Abdullah Ahmad Badawi telah melancarkan Pelan Integriti Nasional (PIN) pada 23 April 2004 (Institut Integriti Malaysia). PIN diperkenalkan selaras dengan cabaran ke4 Wawasan 2020 ke arah pembentukan masyarakat yang kukuh dengan mempunyai nilai moral dan etika murni. Dalam perkara ini, asas pembentukan integriti mesti mempunyai pegangan agama yang kukuh dan rohani yang baik serta budi pekerti yang luhur (Mazilan, Izal Arif \& Suzanna, 2005).

Jadi, artikel ini cuba membincangkan kesedaran pegawai dan anggota PDRM tentang integriti dalam penyampaian perkhidmatan kepolisan. Sebelum itu telah ada kajian tentang persepsi rakyat mengenai gejala rasuah Malaysia pada tahun 2002. Dapatan kajian menunjukkan 15 peratus daripada 7,594 responden mengaku telah terbabit secara langsung dalam aktiviti rasuah dan lebih kurang $20 \%$ pula telah menyaksikan aktiviti rasuah (Loganathan, 2012; Muhammad Aidil, 2011). Kewujudan gejala rasuah dan penyelewengan kini telah menjadi kebimbangan masyarakat untuk hidup secara aman dan harmoni kerana ianya boleh menjejaskan integriti apatah lagi jika membabitkan pegawai dan anggota PDRM.

\section{Isu Integriti dalam Perkhidmatan Kepolisan}

Kepincangan biasa berlaku dalam aktiviti harian - tanpa disedari atau disengajakan - yang menjurus kepada kelemahan pengurusan dan boleh membawa banyak kesan buruk. Dalam proses penyampaian 
perkhidmatan, kelemahan dan kepincangan yang berlaku boleh menjejaskan integriti. Apabila integriti mula merosot, kepercayaan orang awam tentang keupayaan dan kecekapan pegawai dan anggota polis turut merosot. Justeru, pengukuhan integriti telah menjadi agenda penting dalam PDRM kerana mencegah itu lebih baik daripada mengubati.

Bagi tujuan di atas, Suruhanjaya Diraja Penambahbaikan Perjalanan dan Pengurusan PDRM telah dibentuk pada Februari 2004 di bawah Akta Suruhanjaya Inkuiri 1950 bagi memperkasa dan mentransformasikan perkhidmatan kepolisan di Malaysia (Loganathan, 2012). Suruhanjaya itu bertanggungjawab untuk menyiasat aspek peranan, organisasi, sumber manusia, prosedur operasi, penambahbaikan dan pemodenan pasukan PDRM. Hasil siasatan menunjukkan kebimbangan berkaitan isu kepolisan di Malaysia seperti ketiadaan tindakan susulan terhadap laporan yang dibuat; penyalahgunaan kuasa; ketidakcekapan; kurangnya akauntabiliti; perhubungan awam yang lemah; rasuah polis; dan aduan tentang kematian dalam jagaan polis. Semua isu ini menyumbang kepada kemerosotan integriti dalam organisasi PDRM.

Namun, setelah suruhanjaya itu ditamatkan dan cadangan-cadangan yang dikemukakan diterima oleh kerajaan, tetapi suara-suara mengkritik dan mempersoalkan kredibiliti, imej dan integriti PDRM masih berlaku hingga kini. Misalnya, Biro Pengaduan Awam (BPA) melaporkan PDRM adalah agensi menduduki tempat pertama pada tahun 2006 hingga 2009 dan 2011 serta tempat kedua tahun 2010 berkaitan aduan diterima daripada rakyat seperti ditunjukkan dalam Jadual 1. Ini menunjukkan bahawa rakyat masih tidak berpuas hati dengan keberkesanan, kecekapan dan mutu perkhidmatan oleh PDRM walaupun telah melalui proses transformasi (Loganathan, 2012).

Laporan Buletin Integriti PDRM (Bil. 4/2011) (dipetik Loganathan, 2012) tentang maklumat daripada Bahagian Tatatertib menunjukkan seramai 394 anggota polis telah ditahan kerja atas pelbagai kesalahan disiplin dan undang-undang. Laporan itu turut menunjukkan gejala penyalahgunaan dadah dalam pasukan PDRM, di mana masih menjadi satu ancaman serius, di mana sejumlah 195 orang $(0.65 \%)$ dikenal pasti terlibat dengan dadah. Selain masalah dadah dan pelbagai kesalahan lain, pasukan PDRM turut berhadapan dengan kecaman sesetengah pihak dari segi kecekapan, keberkesanan dan sikap berkasar terhadap orang awam selain tidak menunjukkan sikap proaktif dalam menangani isu atau kes yang dilaporkan.

Jadual 1: Agensi Menerima Aduan Tertinggi, 2006-2011

\begin{tabular}{clcccccc}
\hline \multirow{2}{*}{ Bil. } & \multicolumn{1}{c}{ Agensi } & \multicolumn{5}{c}{ Jumlah Aduan Diterima (Tahun) } \\
& & $\mathbf{2 0 0 6}$ & $\mathbf{2 0 0 7}$ & $\mathbf{2 0 0 8}$ & $\mathbf{2 0 0 9}$ & $\mathbf{2 0 1 0}$ & $\mathbf{2 0 1 1}$ \\
\hline 1. & Polis Diraja Malaysia & 194 & 206 & 468 & 785 & 859 & 842 \\
2. & Jabatan Pendaftara Negara & 83 & 76 & 228 & 310 & 335 & 376 \\
3. & Jabatan Kerja Raya & 159 & 126 & 224 & 497 & 638 & 757 \\
4. & Jabatan Imigresen & 83 & 17 & 213 & 274 & 316 & 281 \\
5. & Jabatan Pendidikan Negeri & 164 & 97 & 191 & 311 & 324 & 304 \\
6. & Lembaga Perlesenan Kenderaan & 57 & 23 & 190 & 201 & 223 & 197 \\
& Perdagangan & 183 & 114 & 181 & 219 & 235 & 293 \\
7. & Tenaga Nasional Berhad & 108 & 85 & 168 & 438 & 1123 & 570 \\
8. & Dewan Bandaraya Kuala Lumpur & 58 & 40 & 168 & 152 & 189 & 241 \\
9. & Jabatan Pengangkutan Jalan & 35 & 39 & 164 & 214 & 253 & 268 \\
10. & Bahagian Penguatkuasaan & & & & & & \\
& KPDNHEP & & & & & & \\
\hline
\end{tabular}

Sumber: Dipetik daripada Loganathan (2012)

Jika gelaja-gejala negatif itu tidak dibanteras dan dicegah secara komprehensif oleh PDRM, maka nilai integriti dalam pasukan keselamatan ini lama kelamaan semakin merosot. Hasil kajian oleh Armstrong (2005), Lee-Jones (2018), Parliament of Victoria (2018), Pyo (2008) dan United Nations Office On Drugs and Crime (2011) masing-masing telah membuktikan integriti dan akauntabiliti adalah isu pokok yang menjadi faktor pasukan polis dalam keadaan semakin mencabar. Keadaan yang sama berlaku di 
Malaysia. Kemerosotan integriti dalam PDRM turut dikaitkan dengan motivasi, dorongan dan ganjaran PDRM, nilai teras dan etika PDRM, disiplin dan kawalan dalaman PDRM dan budaya organisasi PDRM (Che Ghazali, 2011; Madzainin, Mohd Nasir \& Mastura, 2017; Mohd Ngaizuddin, 2014; Nursyazlin Yatie \& Noraini, 2017).

Sebagai pasukan di barisan hadapan, PRDM merupakan agensi penting dalam mempromosi integriti dalam melaksanakan perkhidmatan kepolisan di negara ini. Justeru, PDRM perlu lebih kompetitif dan mengambil langkah bersepadu dalam meningkatkan integriti dalam organisasinya. Hal ini penting kerana begitu besar tanggungjawab dan peranan terletak di bahu PDRM bagi menjaga keselamatan negara dan ketenteraman awam (Megat Ayop \& Abd. Halim, 2016a; 2016b). Oleh itu, PDRM perlu mendukung nilai integriti bagi memastikan undang-undang dapat dikuatkuasakan dengan betul dan tepat tanpa sebarang perlanggaran undang-undang dan bertentangan dengan nilai dan etika Perkhidmatan Awam di Malaysia (Jamiah et al., 2007; Mohd Koharuddin et al., 2012; Muzaffar Syah, 2016).

PIN adalah langkah pertama ke arah perkukuhkan integriti dalam PDRM. Justeru, pada sambutan Hari Polis ke-201 tahun 2008, PDRM melancarkan lencana "Integriti Amalan Kita" (Berita Harian, 22 Mac 2008) sebagai simbol mendukung nilai integriti dalam perkhidmatan kepolisan. Melalui PIN, PDRM diseru agar lebih bertanggungjawab melaksanakan amanah demi kepentingan rakyat dengan berpegang kepada nilai integriti yang bertepatan dengan norma masyarakat. Perkara ini merupakan cabaran besar kepada PDRM dalam usaha menerapkan nilai integriti ke arah organisasi penguatkuasaan dan keselamatan yang unggul di Malaysia (Khalid, 2016).

Ekoran itu, PDRM memberi tumpuan kepada tiga fokus utama iaitu: (i) mengekalkan ketenteraman awam dan kesejahteraan rakyat; (ii) mengawal serta mengekang jenayah melalui pencegahan dan penyiasatan berkesan; dan (iii) memantapkan integriti dan pematuhan standard. Bagi memenuhi hasrat itu, tiga buku telah diterbitkan sebagai panduan dan hala cara strategi pasukan PDRM, iaitu: (i) Kod Etika PDRM; (ii) Pelan Integriti PDRM 2016-2020; dan (iii) Manual Pematuhan Standard (Khalid, 2016).

Pelan Integriti PDRM 2016-2020 berpaksikan integriti dan pematuhan standard. Ini adalah pelan penambahbaikan secara berterusan sebagai kesinambungan pelan integriti sebelumnya (2007-2010 dan 2010-2015). Ia memberi fokus ke arah peningkatan integriti, pematuhan standard perkhidmatan PDRM dan mensejahterakan institusi berkeluarga dalam memberi perkhidmatan kepolisan moden kepada masyarakat, di samping membentuk warga PDRM yang berintegriti ke arah kepolisan moden, menutup ruang dan peluang salah laku dalam kalangan warga PDRM melalui pematuhan etika kepolisan dan standard yang ditetapkan serta meningkatkan imej, perkhidmatan kepolisan dan profesionalisme warga PDRM.

Usaha pengukuhan dalam organisasi PDRM terus dilakukan apabila Suruhanjaya Bebas Aduan dan Salah Laku Polis (IPCMC) ditubuhkan pada tahun 2004. Suruhanjaya ini bertujuan menyerlahkan integriti PDRM (Zainudin, 2019). Selepas 15 tahun tertangguh, IPCMC telah menjadi kenyataan setelah mendapat persetujuan PDRM sebagai mekanisme kawal selia di luar ruang lingkup PDRM ke arah memartabatkan semula imej pasukan PDRM. IPCMC bertujuan menghapuskan penolakan, kegelisahan dan bantahan rakyat terhadap PDRM. Justeru, bekas Ketua Polis Negara Tan Abdul Hamid memberi lampu hijau kepada penubuhan IPCMC demi kepentingan anggota pasukan dan orang awam dalam situasi 'menang-menang' (Luqman Arif, 2019).

\section{Apa Itu Integriti?}

Di sini dijelaskan secara ringkas konsep integriti agar ia dapat difahami dalam konteks penyampaian perkhidmatan kepolisan di Malaysia. Umumnya, integriti itu merujuk kualiti unggul yang wujud secara keseluruhan dan padu kepada individu dan organisasi yang berkaitan dengan etika (Institut Integriti Malaysia, 2016). Manakala, integriti penjawat awam merujuk kepada keperluan melaksanakan amanah dan kuasa menurut kepentingan umum. Bagi Heywood, Marquette, Peiffer dan Zuniga (2017), integriti 
dalam kehidupan awam adalah komponen penting bagi mewujudkan kepercayaan rakyat kepada kerajaan.

Walau bagaimanapun, sejak dekad kebelakangan ini, integriti semakin mendapat perhatian di seluruh dunia apabila standard integriti semakin merosot. Rakyat semakin sedar dan memahami kepentingan integriti terutama bagi membendung rasuah dan penyalahgunaan kuasa dalam penyampaian perkhidmatan awam. Gejala-gejala negatif ini boleh melemahkan sistem penyampaian perkhidmatan dan ancaman kepada kerajaan yang baik. Hakikatnya, rasuah boleh dicegah melalui penerapan integriti, bukannya mencegah rasuah untuk mempromosi integriti dalam kalangan penjawat awam. Jadi, membentuk tingkah laku positif melalui integriti lebih penting bagi mencegah tindak laku negatif seperti rasuah (Heywood et al., 2017).

Sementara itu, Charter (1996) mengandaikan bahawa individu mengharapkan integriti dalam dirinya dan juga orang lain kerana integriti itu adalah asas membentuk kepercayaan dalam kalangan individu. Integriti adalah kualiti dan kebaikan yang perlu dimiliki oleh individu termasuklah etika yang baik. Manakala Diamond (2001: 864) memperinci nilai ini seperti "the notion of integrity is inseparable from the idea of a kind of wholeness of self or of a moral identity, which can be forfeited or violated by certain actions". Diamond menyifatkan integriti tidak boleh dipisahkan daripada gagasan keutuhan diri dan identiti moral individu. Semua itu boleh lupus disebabkan pelanggaran nilai-nilai itu disebabkan tindakan atau tingkah laku negatif. Bagi penjawat awam seperti polis, faktor tarikan untuk melakukan tindakan yang menyalahi undang-undang disebabkan keperluan hidup banyak mendorong melakukan pelanggaran terhadap integriti dan amanah yang diberikan.

Analisis Menzel (2005) menunjukkan integriti boleh dinilai melalui perspektif berbeza dengan etika dan urus tadbir iaitu: (i) pembentukan moral dan pembuatan keputusan beretika; (ii) undang-undang etika dan agensi penguatkuasaan; (iii) prestasi organisasi; (iv) pengurusan etika; dan (v) persekitaran etika. Huberts (2014) pula membuat penelitian bahawa integriti boleh dinilai melalui disiplin ilmu seperti pentadbiran awam, falsafah, sosiologi dan antropologi, undang-undang, psikologi, ekonomi dan pentadbiran perniagaan, dan sains politik.

Penelitian para sarjana mengenai nilai integriti kebanyakannya menjurus kepada konteks sosial dan institusi sebagai faktor penyumbang utama dalam pelanggaran integriti. Justeru, Huberts (2014) menjelaskan bahawa kualiti bertindak yang bersesuaian dengan nilai moral, norma dan peraturan amat penting untuk sesuatu tindakan itu berintegriti atau sebaliknya. Jika wujud perlanggaran nilai, norma dan peraturan yang telah diterima dalam sistem sosial yang sedia ada, maka tindakan itu disifatkan tidak berintegriti.

Dalam pada itu, integriti sering dikaitkan dengan nilai seperti kepercayaan, ketekalan dan kebolehpercayaan. Bagi Montefiore (1999), seseorang yang berintegriti adalah individu yang berpegang kepada nilai yang ada dan bertanggungjawab terhadap sebarang tindakan yang dilakukannya. Di sini membuktikan bahawa nilai baik adalah saling berkaitan dengan integriti terutama dalam konteks keikhlasan dan kejujuran melakukan sesuatu tindakan. Atas sebab itu, individu itu perlu menunjukkan keikhlasan dan kejujuran dalam setiap tingkah laku berdasarkan nilai-nilai murni yang menjadi tunjang kepada integriti.

Manakala McFall (1987) menjelaskan integriti itu tidak dapat dipisahkan dengan konsep moral tentang kebaikan. Dalam hal ini, McFall (1987: 16) menjelaskan bahawa "if moral integrity presupposes personal integrity, and personal integrity requires identity-conferring commitments, then moral integrity is, generally, inconsistent with impartiality". Ringkasnya, integriti peribadi memerlukan komitmen pembentukan identiti bagi mewujudkan moral baik bagi individu yang hidup dalam persekitaran sosial yang sangat luas. Dengan kata lain, integriti menghubungkan pelbagai nilai murni dalam masyarakat.

Berdasarkan konsep-konsep yang dijelaskan secara ringkas di atas, integriti itu perlu menjadi tunjang dan tonggak utama dalam menyampaikan perkhidmatan kepolisan di Malaysia. Jadi, integriti itu adalah ibu kepada segala amanah, kebaikan, nilai murni dan moral yang baik. Apabila pegawai dan anggota 
polis memegang nilai integriti itu, mereka boleh membebaskan diri daripada sebarang salah laku, penyalahgunaan kuasa, penyeleweng, rasuah dan sebagainya.

\section{Metod Kajian}

Kerangka analisis dibentuk seperti dalam Rajah 1 di bawah yang memperihal pemboleh ubah bebas (pegawai dan anggota PDRM) dalam melaksanakan tanggungjawab dan penyampaian perkhidmatan kepolisan mempunyai kesan (pengaruh) ke atas integriti sebagai pemboleh ubah bersandar.

Rajah 1: Kerangka Analisis Kajian

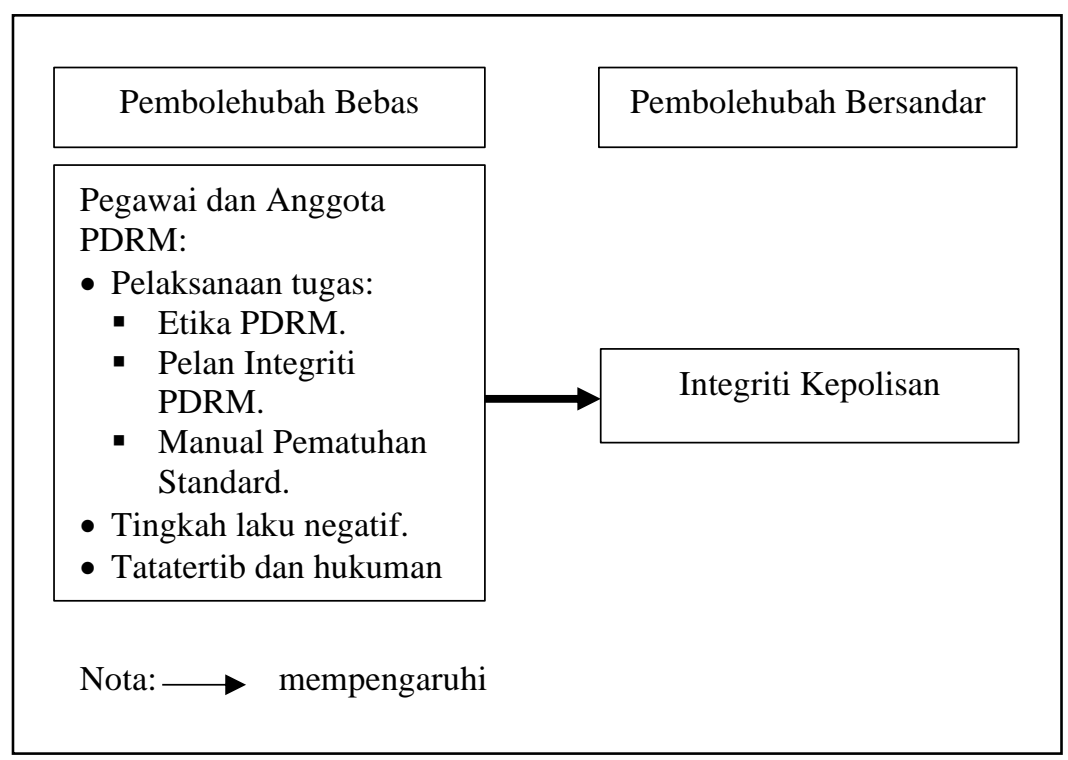

Dalam melaksanakan tugas yang diamanahkan, pegawai dan anggota PDRM mesti berpandu kepada undang-undang dan peraturan yang dikuatkuasakan. Mereka juga perlu mematuhi Etika PDRM, Pelan Integriti PDRM dan Manual Pematuhan Standard yang telah dilancarkan. Namun, tingkah laku negatif yang didorong oleh sesuatu tujuan boleh menjejaskan reputasi dan imej pasukan PDRM. Jika didapati berlaku pelanggaran undang-undang dan etika kerja, pegawai dan anggota PDRM boleh dikenakan tindakan dan hukuman mengikut undang-undang sedia ada. Jadi, pelanggaran undang-undang, peraturan dan etika kerja melibatkan pegawai dan anggota PDRM boleh menjejaskan usaha ke arah pengukuhan integriti.

Kajian ini melibatkan populasi pegawai dan anggota PDRM di Perak. Sampel dipilih melalui kaedah rawak berstrata melibatkan 100 orang pegawai dan anggota PDRM di Ibu Pejabat Polis Daerah Ipoh dan Ibu Pejabat Kontigen Perak. Pemilihan sampel secara rawak berstrata sesuai digunakan dalam kajian ini kerana populasi PDRM Perak tidak seragam, di mana sampel berada dalam jabatan yang berbeza dan melakukan tugas yang berbeza dalam PDRM itu sendiri. Dalam situasi ini, sampel rawak berstrata adalah bersesuaian (Creswell, 2005; Fraenkel \& Wallen, 2007; Mohd. Majid, 1998).

Bagi pengumpulan data primer, soal selidik direka bentuk sebagai instrumen utama. Soalan berstruktur digubal berdasarkan bahagian-bahagian seiringan dengan persoalan kajian yang telah diperincikan. Soalan dalam soal selidik berbentuk tertutup (close ended) kecuali bahagian profil yang menggunakan skala Likert iaitu: (1) sangat tidak bersetuju; (2) tidak bersetuju; (3) tidak pasti; (4) bersetuju; dan (5) sangat bersetuju. Soal selidik dibentuk menggunakan Google Form dan diedarkan kepada responden menggunakan aplikasi WhatsApp.

Data yang diperoleh dianalisis menggunakan perisian SPSS versi 23.0. Analisis data berasaskan statistik deskriptif sahaja berdasarkan ukuran nilai kekerapan, peratusan dan min bagi setiap perkara yang diukur dalam soal selidik. Dapatan kajian yang telah dianalisis dipersembahkan dalam bentuk 
jadual bagi memudahkan pemahaman dan perbincangan secara terperinci item-item seperti ditunjukkan dalam setiap jadual dalam perbincangan berikutnya.

\section{Analisis Dapatan Kajian dan Perbincangan}

Dapatan kajian ini menunjukkan daripada 75 responden atau sebanyak 77.3 peratus (58 orang) adalah lelaki. Majoriti responden adalah beragama Islam (90.7\%), di mana mewakili 88 peratus Melayu dan masing-masing 4 peratus kaum Cina, India dan Iban seperti ditunjukkan dalam Jadual 2.

Jadual 2: Jantina, Agama dan Bangsa

\begin{tabular}{lcc}
\hline Item & Kekerapan & Peratus \\
\hline Jantina & & \\
Lelaki & 58 & 77.3 \\
Perempuan & 17 & 22.7 \\
Jumlah & $\mathbf{7 5}$ & $\mathbf{1 0 0 . 0}$ \\
Agama & Kekerapan & Peratus \\
Islam & 68 & 90.7 \\
Kristian & 1 & 1.3 \\
Buddha & 2 & 2.7 \\
Hindu & 4 & 5.3 \\
Jumlah & $\mathbf{7 5}$ & $\mathbf{1 0 0 . 0}$ \\
Bangsa & Kekerapan & Peratus \\
Melayu & 66 & 88.0 \\
Cina & 3 & 4.0 \\
India & 3 & 4.0 \\
Iban & 3 & 4.0 \\
Jumlah & $\mathbf{7 5}$ & $\mathbf{1 0 0 . 0}$ \\
\hline
\end{tabular}

Dari segi status perkahwinan, dapatan kajian menunjukkan majoriti iaitu 82.7 peratus (62 orang) adalah berkahwin dan selebihnya masih bujang (13.3 peratus) dan duda (4.0 peratus) seperti ditunjukkan dalam Jadual 3.

Jadual 3: Status Perkahwinan

\begin{tabular}{lccc}
\hline & Status & Kekerapan & Peratus \\
\hline Bujang & & 10 & 13.3 \\
Berkahwin & & 62 & 82.7 \\
Duda & & 3 & 4.0 \\
& Jumlah & $\mathbf{7 5}$ & $\mathbf{1 0 0 . 0}$ \\
\hline
\end{tabular}

Statistik turut menunjukkan responden telah berkhidmat mulai tahun 1981 dan terkini pada tahun 2019 dalam PDRM dengan pelbagai jawatan permulaan sewaktu memasuki perkhidmatan polis seperti ditunjukkan dalam Jadual 4. Majoriti responden adalah direkrut sebagai konstabel (73.2 peratus) dan diikuti Inspektor (24.0 peratus). Namun, kini responden telah pun menerima kenaikan pangkat seperti ditunjukkan dalam Jadual 5, di mana suatu peningkatan kerjaya dalam kalangan pegawai dan anggota PDRM.

Jadual 4: Tahun Memasuki PDRM

\begin{tabular}{|c|c|c|}
\hline Jawatan Permulaan PDRM & Kekerapan & Peratus \\
\hline ASP & 1 & 1.3 \\
\hline Inspektor & 18 & 24.0 \\
\hline Konstabel & 55 & 73.2 \\
\hline Sarjan & 1 & 1.3 \\
\hline Jumlah & 75 & 100.0 \\
\hline
\end{tabular}


Jadual 5: Jawatan Terkini Dalam PDRM

\begin{tabular}{|c|c|c|}
\hline Jawatan Terkini Dalam PDRM & Kekerapan & Peratus \\
\hline Asistan Komisioner Polis (ACP) & 1 & 1.3 \\
\hline Superintenden Polis (SUPT.) & 2 & 2.7 \\
\hline Deputi Superintenden Polis (DSP) & 6 & 8.0 \\
\hline Asistan Superintenden Polis (ASP) & 8 & 10.7 \\
\hline Inspektor & 4 & 5.3 \\
\hline Sarjan Mejar & 2 & 2.7 \\
\hline Sarjan & 7 & 9.3 \\
\hline Koperal & 26 & 34.7 \\
\hline Lans Koperal & 9 & 12.0 \\
\hline Konstabel & 10 & 13.3 \\
\hline Jumlah & 75 & 100.0 \\
\hline
\end{tabular}

Dalam tempoh perkhidmatan, sebanyak 65.3 peratus (49 orang) pernah menerima Anugerah Perkhidmatan Cemerlang (APC) seperti ditunjukkan dalam Jadual 6. APC merupakan pengiktirafan di atas kecemerlangan yang telah ditunjukkan dalam melaksanakan tugas. Dalam pada itu, Jadual 6 menunjukkan majoriti pegawai dan anggotan PDRM yang terlibat dalam kajian ini berkhidmat di IPK Perak 86.7 peratus (65 orang) seperti ditunjukkan dalam Jadual 7.

Jadual 6: Anugerah Perkhidmatan Cemerlang

\begin{tabular}{lccc}
\hline & Anugerah (APC) & Kekerapan & Peratus \\
\hline Pernah & & 49 & 65.3 \\
Tidak pernah & & 26 & 34.7 \\
& Jumlah & $\mathbf{7 5}$ & $\mathbf{1 0 0 . 0}$ \\
\hline
\end{tabular}

Jadual 7: Tempat Berkhidmat Terkini

\begin{tabular}{lccc}
\hline & Tempat Bertugas & Kekerapan & Peratus \\
\hline IPD Ipoh & & 65 & 86.7 \\
IPK Perak & & 13.3 & 13.3 \\
& Jumlah & $\mathbf{7 5}$ & $\mathbf{1 0 0 . 0}$ \\
\hline
\end{tabular}

\section{Dasar Ke Arah Pemantapan Integriti Dalam PRDM}

Penilaian responden terhadap soalan yang dikemukakan mengikut setiap bahagian pada keseluruhannya adalah tinggi seperti ditunjukkan dalam Jadual 8. Bagi strategi memperkasa sumber manusia dan hala gerak kerja PDRM, nilai min 4.58 menunjukkan kesedaran dan pemahaman responden adalah tinggi mengenai hal ini. Bagi min keseluruhan program pemantapan integriti dalam pasukan PDRM iaitu 4.27 dan kesedaran akauntabiliti awam dalam melaksanakan tugas dan tanggungjawab, di mana penilaian responden menunjukkan nilai min 4.12.

Jadual 8: Nilai Min Keseluruhan Bagi Kumpulan

\begin{tabular}{lccccc}
\hline \multicolumn{1}{c}{ Kumpulan } & N & Minimum & Maksimum & Min & Sisihan Piawai \\
\hline $\begin{array}{l}\text { Strategi memperkasa sumber } \\
\text { manusia dan hala gerak }\end{array}$ & 68 & 3.24 & 5.00 & 4.58 & .43987 \\
$\begin{array}{l}\text { kerja. } \\
\begin{array}{l}\text { Pemantapan integriti dalam } \\
\text { pasukan PDRM. }\end{array}\end{array}$ & 73 & 3.11 & 5.00 & 4.27 & .42668 \\
\hline
\end{tabular}



DOI: https://doi.org/10.47405/mjssh.v6i9.1024

\begin{tabular}{llllll}
$\begin{array}{l}\text { Kesedaran akauntailiti } \\
\text { awam. }\end{array}$ & 72 & 3.07 & 5.00 & 4.12 & .51800 \\
\hline
\end{tabular}

Tiga fokus utama PDRM dalam usaha memperkasa sumber manusia dan hala cara strategi pasukan mulai 2016 hingga 2020 bagi memelihara dan mengekalkan keamanan, iaitu: (i) mengekalkan ketenteraman awam dan kesejahteraan rakyat; (ii) mengawal serta mengekang jenayah melalui pencegahan dan penyiasatan berkesan; dan (iii) memantapkan integriti dan pematuhan standard. Berdasarkan penilaian responden seperti ditunjukkan dalam Jadual 9, jelas membuktikan bahawa responden memahami tujuan dan matlamat yang telah dilakukan oleh PDRM itu, di mana nilai min masing-masing 4.77, 4.75 dan 4.68 adalah tinggi. Dari segi pengukuran, masing-masing melebihi 90 peratus menilai sangat bersetuju dan bersetuju dengan pernyataan yang dikemukakan.

Jadual 9: Fokus Utama Bagi Memelihara dan Mengekalkan Keamanan

\begin{tabular}{|c|c|c|c|c|c|c|c|c|}
\hline \multirow{2}{*}{ Item Diukur } & \multicolumn{5}{|c|}{ Penilaian } & \multirow{2}{*}{$\begin{array}{l}\text { Total } \\
100 \% \\
\end{array}$} & \multirow{2}{*}{ Min } & \multirow{2}{*}{$\begin{array}{l}\text { Sisihan } \\
\text { Piawai }\end{array}$} \\
\hline & 1 & 2 & 3 & 4 & 5 & & & \\
\hline $\begin{array}{l}\text { Mengekalkan ketenteraman } \\
\text { awam dan kesejahteraan rakyat. }\end{array}$ & & & $\begin{array}{c}(1) \\
1.3 \%\end{array}$ & $\begin{array}{c}(15) \\
20.0 \%\end{array}$ & $\begin{array}{c}(59) \\
78.7 \%\end{array}$ & $\begin{array}{c}(75) \\
100.0 \%\end{array}$ & 4.77 & .452 \\
\hline $\begin{array}{l}\text { Mengawal serta mengekang } \\
\text { jenayah melalui pencegahan dan } \\
\text { penyiasatan berkesan. }\end{array}$ & & $\begin{array}{l}(1) \\
1.3 \%\end{array}$ & $\begin{array}{c}(1) \\
1.3 \%\end{array}$ & $\begin{array}{c}(14) \\
18.7 \%\end{array}$ & $\begin{array}{c}(59) \\
78.7 \%\end{array}$ & $\begin{array}{c}(75) \\
100.0 \%\end{array}$ & 4.75 & .548 \\
\hline $\begin{array}{l}\text { Memantapkan integriti dan } \\
\text { pematuhan standard. }\end{array}$ & & & $\begin{array}{c}(6) \\
8.0 \%\end{array}$ & $\begin{array}{c}(12) \\
16.0 \%\end{array}$ & $\begin{array}{c}(57) \\
76.0 \%\end{array}$ & $\begin{array}{c}(75) \\
100.0 \%\end{array}$ & 4.68 & .619 \\
\hline
\end{tabular}

Bagi merealisasikan usaha di atas, pasukan PDRM telah menerbitkan tiga buah buku sebagai panduan dan hala cara strategi ke arah menegakkan integriti. Penerbitan itu bertujuan mendokumentasikan secara formal panduan bagi memahami proses, prosedur dan amalan berkaitan etika dan integriti dalam kalangan pegawai dan anggota PDRM. Penilaian ke atas ketiga-tiga panduan itu masing-masing menunjukkan nilai min yang tinggi 4.52, 4.42 dan 4.41 seperti dalam Jadual 10. Nilai-nilai ini membuktikan pegawai dan anggota PDRM sedia maklum dan mengetahui kewujudan serta keperluan ketiga-tiga panduan itu dalam melaksanakan tugasan masing-masing. Dari segi maklum balas bersetuju dan sangat bersetuju, nilai pengukuran adalah tinggi iaitu Kod Etika PDRM iaitu 93.3 peratus, Pelan Integriti PDRM pula 92.9 peratus dan Manual Pematuhan Standard adalah 89.3 peratus.

Jadual 10: Buku Panduan Pengukuhan Integriti

\begin{tabular}{|c|c|c|c|c|c|c|c|}
\hline \multirow{2}{*}{ Item Diukur } & \multicolumn{4}{|l|}{ Penilaian } & \multirow{2}{*}{$\begin{array}{l}\text { Total } \\
100 \%\end{array}$} & \multirow{2}{*}{ Min } & \multirow{2}{*}{$\begin{array}{l}\text { Sisihan } \\
\text { Piawai }\end{array}$} \\
\hline & 122 & 3 & 4 & 5 & & & \\
\hline $\begin{array}{l}\text { Kod Etika Polis Diraja Malaysia } \\
\text { (PDRM). }\end{array}$ & \multirow{4}{*}{$\begin{array}{c}(1) \\
1.4 \%\end{array}$} & $\begin{array}{c}(5) \\
6.7 \%\end{array}$ & $\begin{array}{c}(26) \\
34.7 \%\end{array}$ & $\begin{array}{c}(44) \\
58.7 \%\end{array}$ & $\begin{array}{c}(75) \\
100.0 \%\end{array}$ & 4.52 & 623 \\
\hline Pelan Integriti Polis Diraja & & $(6)$ & (27) & $(40)$ & $(74)$ & 442 & 750 \\
\hline Malaysia 2016-2020. & & $8.1 \%$ & $36.5 \%$ & $54.1 \%$ & $100.0 \%$ & 4.42 & .159 \\
\hline Manual Pematuhan Standard. & & $\begin{array}{c}(8) \\
10.7 \%\end{array}$ & $\begin{array}{c}(28) \\
37.3 \%\end{array}$ & $\begin{array}{c}(39) \\
52.0 \%\end{array}$ & $\begin{array}{c}(75) \\
100.0 \%\end{array}$ & 4.41 & .680 \\
\hline
\end{tabular}

Dari segi pemahaman tentang Kod Etika PDRM, ia sangat membantu ke arah menegakkan integriti awam sewaktu menjalankan tugas berasaskan nilai-nilai seperti ditunjukkan dalam Jadual 11 yang keseluruhannya memberi petunjuk bahawa responden sedia maklum dan memahami tujuan buku Kod Etika PDRM itu diterbitkan. Jadi, beberapa nilai yang cuba dibentuk seperti keprihatinan dan komitmen; responsif; teras perkhidmatan; semangat kerja berpasukan; inovatif dan kreativiti; dan profesional, di mana menunjukkan yang sangat tinggi daripada 4.49 hingga mencecah 4.73. Bersandarkan kepada nilai-nilai min ini, jelas membuktikan bahawa ada kesedaran dan kesungguhan dalam kalangan pegawai dan anggota polis berusaha memperkukuh etika kerja ke arah membentuk integriti dalam pasukan PDRM. 
DOI: https://doi.org/10.47405/mjssh.v6i9.1024

Jadual 11: Pemupukan Nilai Murni Melalui Kod Etika PDRM

\begin{tabular}{|c|c|c|c|c|c|c|c|}
\hline \multirow{2}{*}{ Item Diukur } & \multicolumn{4}{|l|}{ Penilaian } & \multirow{2}{*}{$\begin{array}{l}\text { Total } \\
100 \% \\
\end{array}$} & \multirow{2}{*}{ Min } & \multirow{2}{*}{$\begin{array}{l}\text { Sisihan } \\
\text { Piawai }\end{array}$} \\
\hline & 122 & 3 & 4 & 5 & & & \\
\hline Lebih prihatin dan komited & & (7) & $(24)$ & $(44)$ & $(75)$ & 440 & 665 \\
\hline melaksanakan fungsi PDRM. & & $9.3 \%$ & $32.0 \%$ & $58.7 \%$ & $100.0 \%$ & 4.49 & (603. \\
\hline $\begin{array}{l}\text { Responsif dalam memberi } \\
\text { perkhidmatan terbaik kepada }\end{array}$ & & $(4)$ & $(240$ & $(47)$ & $(75)$ & 4.57 & .597 \\
\hline masyarakat. & & $5.3 \%$ & $32.0 \%$ & $62.7 \%$ & $100.0 \%$ & $4 . J 1$ & \\
\hline Integriti sebagai teras & & $(3)$ & $(20)$ & $(52)$ & $(75)$ & 4.65 & .557 \\
\hline perkhidmatan. & & $4.0 \%$ & $26.7 \%$ & $69.3 \%$ & $100.0 \%$ & 4.05 & IJ. \\
\hline $\begin{array}{l}\text { Semangat satu pasukan menjadi } \\
\text { budaya ke arah mencapai misi dan }\end{array}$ & & $(2)$ & $(16)$ & $\begin{array}{l}(57) \\
760 \%\end{array}$ & $(75)$ & 4.73 & .502 \\
\hline visi. & & & $21.3 \%$ & $76.0 \%$ & $100.0 \%$ & & \\
\hline $\begin{array}{l}\text { Inovatif dan kreatif menjadi } \\
\text { amalan dalam meningkatkan }\end{array}$ & & (3) & (26) & $(46)$ & (75) & 57 & 574 \\
\hline kualiti perkhidmatan. & & $4.0 \%$ & $34.7 \%$ & $61.3 \%$ & $100.0 \%$ & 4.51 & .514 \\
\hline Profesional ke arah & & $(3)$ & $(22)$ & $(50)$ & $(75)$ & 463 & 564 \\
\hline merealisasikan Kepolisan Moden. & & $4.0 \%$ & $29.3 \%$ & $66.7 \%$ & $100.0 \%$ & & \\
\hline
\end{tabular}

Manakala pengenalan Pelan Integriti PDRM pula bertujuan memantapkan pengurusan, meningkatkan keberkesanan sistem penyampaian, pemantapan pengurusan modal insan, memperkasa imej PDRM dan mensejahterakan institusi keluarga. Dari segi penilaian, jelas menunjukkan lima teras itu memberi nilai min tinggi daripada 4.51 hingga 4.64. Ini jelas membuktikan pegawai dan anggota PDRM mempunyai kesedaran tinggi dan kefahaman yang jelas mengenai matlamat yang ingin dibentuk oleh PDRM ke arah menegakkan integriti dalam perkhidmatan kepolisan. Dari segi penilaian bersetuju dan sangat bersetuju, lima strategi (item) yang dikemukakan seperti dalam Jadual 12 adalah sangat tinggi yang semuanya melepasi 92 peratus ke atas.

Jadual 12: Teras Strategi Dalam Pelan Integriti PDRM 2016-2020

\begin{tabular}{|c|c|c|c|c|c|c|c|c|}
\hline \multirow{2}{*}{ Item Diukur } & \multicolumn{5}{|c|}{ Penilaian } & \multirow{2}{*}{$\begin{array}{l}\text { Total } \\
100 \%\end{array}$} & \multirow{2}{*}{ Min } & \multirow{2}{*}{$\begin{array}{l}\text { Sisihan } \\
\text { Piawai }\end{array}$} \\
\hline & 1 & 2 & 3 & 4 & 5 & & & \\
\hline $\begin{array}{l}\text { Memantapkan pengurusan } \\
\text { pentadbiran dan pematuhan } \\
\text { standard. }\end{array}$ & $\begin{array}{l}(1) \\
1.3 \%\end{array}$ & & $\begin{array}{c}(3) \\
4.0 \%\end{array}$ & $\begin{array}{c}(26) \\
34.7 \%\end{array}$ & $\begin{array}{l}(45) \\
60.0 \%\end{array}$ & $\begin{array}{c}(75) \\
100.0 \%\end{array}$ & 4.52 & .704 \\
\hline $\begin{array}{l}\text { Meningkatkan keberkesanan } \\
\text { sistem perkhidmatan } \\
\text { penyampaian. }\end{array}$ & $\begin{array}{l}(1) \\
1.3 \%\end{array}$ & & $\begin{array}{l}(4) \\
5.3 \%\end{array}$ & $\begin{array}{c}(25) \\
33.3 \%\end{array}$ & $\begin{array}{l}(45) \\
60.0 \%\end{array}$ & $\begin{array}{c}(75) \\
100.0 \%\end{array}$ & 4.51 & .724 \\
\hline $\begin{array}{l}\text { Memantapkan pengurusan } \\
\text { sumber manusia. }\end{array}$ & $\begin{array}{l}(1) \\
1.3 \%\end{array}$ & & $\begin{array}{l}(5) \\
6.7 \%\end{array}$ & $\begin{array}{c}(20) \\
26.7 \%\end{array}$ & $\begin{array}{l}(49) \\
65.3 \%\end{array}$ & $\begin{array}{c}(75) \\
100.0 \%\end{array}$ & 4.55 & .741 \\
\hline $\begin{array}{l}\text { Memperkasa imej PDRM ke arah } \\
\text { kepolisan moden. }\end{array}$ & $\begin{array}{l}(1) \\
1.3 \%\end{array}$ & & $\begin{array}{l}(3) \\
4.0 \%\end{array}$ & $\begin{array}{c}(17) \\
22.7 \%\end{array}$ & $\begin{array}{c}(54) \\
72.0 \%\end{array}$ & $\begin{array}{c}(75) \\
100.0 \%\end{array}$ & 4.64 & .690 \\
\hline $\begin{array}{l}\text { Mensejahterakan institusi } \\
\text { keluarga. }\end{array}$ & $\begin{array}{l}(1) \\
1.3 \%\end{array}$ & $\begin{array}{l}(1) \\
1.3 \%\end{array}$ & $\begin{array}{l}(6) \\
8.0 \%\end{array}$ & $\begin{array}{c}(20) \\
26.7 \%\end{array}$ & $\begin{array}{l}(47) \\
62.7 \%\end{array}$ & $\begin{array}{c}(75) \\
100.0 \%\end{array}$ & 4.48 & .811 \\
\hline
\end{tabular}

Sementara itu, Manual Pematuhan Standard PDRM merupakan inisiatif untuk mentransformasikan pasukan PDRM secara holistik dan memperkasa integriti warga PDRM. Ini selari dengan dasar nasional untuk mewujudkan pentadbiran kerajaan dan perkhidmatan awam yang cekap, berdisiplin serta berintegriti tinggi. Manual itu adalah garis panduan berbentuk dokumen bertulis sebagai sumber rujukan seperti ditunjukkan dalam Jadual 13. Analisis menunjukkan nilai min setiap item yang diukur adalah tinggi daripada 4.39 bagi ISO 9001:2008 kepada 4.68 bagi Perintah Tetap Ketua Polis Negara. Jadi, berdasarkan nilai min itu, pegawai dan anggota PDRM sebenarnya memahami sumber-sumber asas pembentukan manual tersebut. Dari segi nilai peratus yang diperolehi, kesemua item yang diukur mencapai nilai yang lebih daripada 90 peratus ke atas bagi penilaian bersetuju dan sangat bersetuju. 
Jadual 13: Sumber-sumber Manual Pematuhan Standard PRDM

\begin{tabular}{|c|c|c|c|c|c|c|c|c|}
\hline \multirow{2}{*}{ Item Diukur } & \multicolumn{5}{|c|}{ Penilaian } & \multirow{2}{*}{$\begin{array}{l}\text { Total } \\
100 \% \\
\end{array}$} & \multirow{2}{*}{ Min } & \multirow{2}{*}{$\begin{array}{l}\text { Sisihan } \\
\text { Piawai }\end{array}$} \\
\hline & 1 & 2 & 3 & 4 & 5 & & & \\
\hline Pekeliling Perkhidmatan. & & & $\begin{array}{c}(5) \\
6.7 \%\end{array}$ & $\begin{array}{c}(33) \\
44.0 \%\end{array}$ & $\begin{array}{c}(37) \\
49.3 \%\end{array}$ & $\begin{array}{c}(75) \\
100.0 \%\end{array}$ & 4.43 & .619 \\
\hline Perintah Tetap Ketua Polis Negara. & & & $\begin{array}{c}(3) \\
4.0 \%\end{array}$ & $\begin{array}{c}(18) \\
24.0 \%\end{array}$ & $\begin{array}{c}(54) \\
72.0 \%\end{array}$ & $\begin{array}{c}(75) \\
100.0 \%\end{array}$ & 4.68 & .549 \\
\hline Standard Operating Procedure. & & & $\begin{array}{c}(3) \\
4.0 \%\end{array}$ & $\begin{array}{c}(26) \\
34.7 \%\end{array}$ & $\begin{array}{c}(46) \\
61.3 \%\end{array}$ & $\begin{array}{c}(75) \\
100.0 \%\end{array}$ & 4.57 & .574 \\
\hline Arahan-Arahan Pentadbiran. & & & $\begin{array}{c}(4) \\
5.3 \%\end{array}$ & $\begin{array}{c}(25) \\
33.3 \%\end{array}$ & $\begin{array}{c}(46) \\
61.3 \%\end{array}$ & $\begin{array}{c}(75) \\
100.0 \%\end{array}$ & 4.56 & .598 \\
\hline ISO 9001:2008. & $\begin{array}{c}(2) \\
2.7 \%\end{array}$ & $\begin{array}{c}(1) \\
1.4 \%\end{array}$ & $\begin{array}{c}(5) \\
6.8 \%\end{array}$ & $\begin{array}{c}(24) \\
32.4 \%\end{array}$ & $\begin{array}{c}(42) \\
56.8 \%\end{array}$ & $\begin{array}{c}(74) \\
100.0 \%\end{array}$ & 4.39 & .889 \\
\hline Manual Prosedur Kerja. & & & $\begin{array}{c}(7) \\
9.3 \%\end{array}$ & $\begin{array}{c}(25) \\
33.3 \%\end{array}$ & $\begin{array}{c}(43) \\
57.3 \%\end{array}$ & $\begin{array}{c}(75) \\
100.0 \%\end{array}$ & 4.48 & .665 \\
\hline Pembahagian Tugas. & & & $\begin{array}{c}(6) \\
8.1 \%\end{array}$ & $\begin{array}{c}(28) \\
37.8 \%\end{array}$ & $\begin{array}{c}(40) \\
54.1 \%\end{array}$ & $\begin{array}{c}(74) \\
100.0 \%\end{array}$ & 4.46 & .645 \\
\hline
\end{tabular}

Manual Pematuhan Standard PDRM menjadi mekanisme 'kawal selia' dalam memastikan pematuhan kepada semua arahan, peraturan dan undang-undang yang terpakai melalui objektif-objektif seperti ditunjukkan dalam Jadual 14. Manual itu bertujuan mewujudkan perkhidmatan kepolisan moden yang berintegriti (min 4.57) dengan 97.3 peratus responden (bersetuju dan sangat bersetuju) tentang objektif itu; meningkatkan kualiti dan prestasi pentadbiran dan penyampaian perkhidmatan (min 4.53) dan 94.7 peratus bersetuju dan sangat bersetuju; sistem kerja berteraskan pematuhan standard (min 4.53) dan penilaian bersetuju dan sangat bersetuju adalah 97.3 peratus; dan tindakan pencegahan dan pemulihan bagi memulihkan integriti PDRM dengan nilai min 4.55 dan penilaian bersetuju dan sangat bersetuju adalah 93.3 peratus. Berdasarkan kepada nilai yang ditunjukkan menjelaskan bahawa pegawai dan anggota PDRM mengetahui objektif manual itu dilancarkan. Justeru, apabila manual itu dapat diikuti dalam pelaksanaan tugas, maka integriti awam melibatkan pegawai dan anggota PDRM dapat dimantapkan.

Jadual 14: Objektif Manual Pematuhan Standard PDRM

\begin{tabular}{|c|c|c|c|c|c|c|c|c|}
\hline \multirow{2}{*}{ Item Diukur } & \multicolumn{5}{|c|}{ Penilaian } & \multirow{2}{*}{$\begin{array}{l}\text { Total } \\
100 \%\end{array}$} & \multirow{2}{*}{ Min } & \multirow{2}{*}{$\begin{array}{l}\text { Sisihan } \\
\text { Piawai }\end{array}$} \\
\hline & 1 & 2 & 3 & 4 & 5 & & & \\
\hline Mewujudkan perkhidmatan & & & $(2)$ & $(28)$ & $(44)$ & $(74)$ & \multirow{3}{*}{4.57} & \multirow[b]{2}{*}{.551} \\
\hline kepolisan moden yang berintegriti. & & & $2.7 \%$ & $37.8 \%$ & $59.5 \%$ & $100.0 \%$ & & \\
\hline $\begin{array}{l}\text { Meningkatkan kualiti serta prestasi } \\
\text { pentadbiran dan penyampaian }\end{array}$ & & & & & & & & \multirow{4}{*}{.600} \\
\hline perkhidmatan kepolisan, seiring & & & $(4)$ & $(27)$ & $(44)$ & $(75)$ & \multirow{3}{*}{4.53} & \\
\hline $\begin{array}{l}\text { dengan tuntutan masyarakat } \\
\text { terhadap pasukan PDRM sebagai } \\
\text { pelindung utama negara. }\end{array}$ & & & $5.3 \%$ & $36.0 \%$ & $58.7 \%$ & $100.0 \%$ & & \\
\hline Menyediakan sistem kerja & & & & & & & & \\
\hline kepolisan yang berteraskan & & & $(2)$ & $(31)$ & $(42)$ & $(75)$ & \multirow{2}{*}{4.53} & \multirow{2}{*}{.553} \\
\hline $\begin{array}{l}\text { pematuhan standard yang telah } \\
\text { ditetapkan. }\end{array}$ & & & $2.7 \%$ & $41.3 \%$ & $56.0 \%$ & $100.0 \%$ & & \\
\hline Mengenal pasti tindakan & & & $(5)$ & (24) & (46) & $(75)$ & \multirow{2}{*}{4.55} & \multirow{2}{*}{.622} \\
\hline $\begin{array}{l}\text { pencegahan serta pemulihan bagi } \\
\text { mengatasi isu integriti pasukan. }\end{array}$ & & & $6.7 \%$ & $32.0 \%$ & $61.3 \%$ & $100.0 \%$ & & \\
\hline
\end{tabular}


DOI: https://doi.org/10.47405/mjssh.v6i9.1024

Manual Pematuhan Standard PDRM mengandungi enam prinsip seperti ditunjukkan dalam Jadual 15 yang perlu dijulang oleh pegawai dan anggota PDRM bagi meningkatkan integriti dan akauntabiliti perkhidmatan yang cemerlang. Semua prinsip itu dianalisis menunjukkan nilai min tinggi dari 4.61 hingga 4.73. Ini memberi gambaran pegawai dan anggota PDRM sentiasa mendukung prinsip-prinsip itu sewaktu menjalankan tugas dan memberikan perkhidmatan kepolisan yang berkesan dan cekap kepada masyarakat dan negara. Dari segi penilaian (bersetuju dan sangat bersetuju) semuanya melebihi 90 peratus ke atas. Jadi, kesetiaan; kepimpinan; akauntabiliti; tepat dan berkesan; konsisten; dan telus dan tegas adalah nilai yang menjadi pegangan pegawai dan anggota PDRM ke arah pengukuhan integriti.

Jadual 15: Prinsip-prinsip Dalam Manual Pematuhan Standard

\begin{tabular}{|c|c|c|c|c|c|c|c|c|}
\hline \multirow{2}{*}{ Item Diukur } & \multicolumn{5}{|c|}{ Penilaian } & \multirow{2}{*}{$\begin{array}{l}\text { Total } \\
100 \%\end{array}$} & \multirow{2}{*}{ Min } & \multirow{2}{*}{$\begin{array}{l}\text { Sisihan } \\
\text { Piawai }\end{array}$} \\
\hline & 1 & 2 & 3 & 4 & 5 & & & \\
\hline \multirow{2}{*}{ Kesetiaan. } & & $(1)$ & (4) & $(18)$ & (52) & $(75)$ & \multirow{2}{*}{4.61} & \multirow{2}{*}{.655} \\
\hline & & $1.3 \%$ & $5.3 \%$ & $24.0 \%$ & $69.3 \%$ & $100.0 \%$ & & \\
\hline \multirow{2}{*}{ Kepimpinan. } & & & $(3)$ & (16) & (56) & (75) & \multirow{2}{*}{4.71} & \multirow{2}{*}{.540} \\
\hline & & & $4.0 \%$ & $21.3 \%$ & $74.7 \%$ & $100.0 \%$ & & \\
\hline \multirow{2}{*}{ Akauntabiliti. } & & & $(2)$ & (18) & (54) & (74) & \multirow{2}{*}{4.70} & \multirow{2}{*}{.516} \\
\hline & & & $2.7 \%$ & $24.3 \%$ & $73.0 \%$ & $100.0 \%$ & & \\
\hline \multirow{2}{*}{ Tepat dan berkesan. } & & & (5) & (13) & (56) & (74) & \multirow{2}{*}{4.69} & .595 \\
\hline & & & $\begin{array}{l}0.8 \% \\
(5)\end{array}$ & $\begin{array}{c}17.6 \% \\
(16)\end{array}$ & $\begin{array}{l}75.7 \% \\
(53)\end{array}$ & $\begin{array}{c}100.0 \% \\
(74)\end{array}$ & & \multirow[b]{2}{*}{.607} \\
\hline Konsisten. & & & $6.8 \%$ & $21.6 \%$ & $71.6 \%$ & $100.0 \%$ & 4.65 & \\
\hline \multirow[t]{2}{*}{ Telus dan adil. } & & & $(3)$ & (14) & (58) & $(75)$ & \multirow{2}{*}{4.73} & \multirow{2}{*}{.528} \\
\hline & & & $4.0 \%$ & $18.7 \%$ & $77.3 \%$ & $100.0 \%$ & & \\
\hline
\end{tabular}

\section{Ke Arah Pemantapan Integriti Dalam Pasukan PDRM}

Jadual 16 memperihal usaha-usaha yang telah dilakukan oleh PDRM ke arah memupuk nilai-nilai murni dalam kalangan pegawai dan anggotanya melalui pelbagai program dan dasar seperti telah dibincangkan di atas. Jadi, dalam usaha pemantapan itu, responden ditanya tentang bagaimana dalam diri masing-masing mengenai kefahaman, keyakinan, tindakan sewaktu melakukan tugas, kecenderungan melakukan rasuah, melaporkan salah laku dan sebagainya. Atas penilaian yang telah dibuat oleh responden, jelas menunjukkan mereka sedar dan memahami peri pentingnya dalam diri masing-masing ada nilai bertanggungjawab dan keinginan untuk mengekalkan atau mempertingkat integriti dalam diri masing-masing. Bahkan dalam masa yang sama rela kehilangan kenaikan pangkat apabila berani untuk melaporkan salah laku, rasuah dan sebagainya kepada pihak pengurusan atasan, SPRM dan kerajaan. Ini menggambarkan nilai akauntabiliti yang ada dalam diri pegawai dan anggota PDRM dalam membentuk budaya dan nilai integriti dalam PDRM.

Jadual 16: Pemupukan Nilai Murni Melalui Kod Etika PDRM

\begin{tabular}{|c|c|c|c|c|c|c|c|c|}
\hline \multirow{2}{*}{ Item Diukur } & \multicolumn{5}{|c|}{ Penilaian } & \multirow{2}{*}{$\begin{array}{l}\text { Total } \\
100 \% \\
\end{array}$} & \multirow{2}{*}{ Min } & \multirow{2}{*}{$\begin{array}{l}\text { Sisihan } \\
\text { Piawai }\end{array}$} \\
\hline & 1 & 2 & 3 & 4 & 5 & & & \\
\hline Anda memahami maksud & & & (4) & $(32)$ & (37) & $(73)$ & & \\
\hline integriti. & & & $5.5 \%$ & $43.8 \%$ & $50.7 \%$ & $100.0 \%$ & & .002 \\
\hline Anda yakin diri anda seorang & & & (3) & $(36)$ & $(36)$ & $(75)$ & 444 & 575 \\
\hline yang berintegriti. & & & $4.0 \%$ & $48.0 \%$ & $48.0 \%$ & $100.0 \%$ & 4.44 & נI \\
\hline $\begin{array}{l}\text { Sentiasa melakukan tugas } \\
\text { mengikut SOP, kod etika dan } \\
\text { manual kerja yang sedia ada. }\end{array}$ & & & $\begin{array}{c}(7) \\
9.3 \%\end{array}$ & $\begin{array}{c}(31) \\
41.3 \%\end{array}$ & $\begin{array}{c}(37) \\
49.3 \%\end{array}$ & $\begin{array}{c}(75) \\
100.0 \%\end{array}$ & 4.40 & .658 \\
\hline $\begin{array}{l}\text { Tidak pernah bertolak ansur } \\
\text { perbuatan melanggar etika kerja } \\
\text { dan undang-undang. }\end{array}$ & $\begin{array}{c}(4) \\
5.3 \%\end{array}$ & $\begin{array}{c}(4) \\
5.3 \%\end{array}$ & $\begin{array}{c}(10) \\
13.3 \%\end{array}$ & $\begin{array}{c}(27) \\
36.0 \%\end{array}$ & $\begin{array}{c}(30) \\
40.0 \%\end{array}$ & $\begin{array}{c}(75) \\
100.0 \%\end{array}$ & 4.00 & 1.115 \\
\hline
\end{tabular}


DOI: https://doi.org/10.47405/mjssh.v6i9.1024

\begin{tabular}{|c|c|c|c|c|c|c|c|c|}
\hline $\begin{array}{l}\text { Pernah diberi teguran lisan dan } \\
\text { surat amaran kerana kesilapan } \\
\text { sewaktu bertugas, tetapi tidak } \\
\text { dikenakan tindakan tataterbit. }\end{array}$ & $\begin{array}{c}(21) \\
28.0 \%\end{array}$ & $\begin{array}{c}(3) \\
4.0 \%\end{array}$ & $\begin{array}{c}(17) \\
22.7 \%\end{array}$ & $\begin{array}{c}(19) \\
25.3 \%\end{array}$ & $\begin{array}{c}(15) \\
20.0 \%\end{array}$ & $\begin{array}{c}(75) \\
100.0 \%\end{array}$ & 3.05 & 1.497 \\
\hline $\begin{array}{l}\text { Berusaha perbaiki kesilapan } \\
\text { demi integriti pasukan PDRM. }\end{array}$ & & & $\begin{array}{c}(3) \\
4.0 \%\end{array}$ & $\begin{array}{c}(32) \\
42.7 \%\end{array}$ & $\begin{array}{c}(40) \\
53.3 \%\end{array}$ & $\begin{array}{c}(75) \\
100.0 \%\end{array}$ & 4.49 & .578 \\
\hline $\begin{array}{l}\text { Memberi } 100 \% \text { tumpuan } \\
\text { terhadap tugas demi mengelak } \\
\text { kesilapan dan kecuaian. }\end{array}$ & & & $\begin{array}{c}(2) \\
2.7 \%\end{array}$ & $\begin{array}{c}(24) \\
32.0 \%\end{array}$ & $\begin{array}{l}(49) \\
65.3 \%\end{array}$ & $\begin{array}{c}(75) \\
100.0 \%\end{array}$ & 4.63 & .540 \\
\hline $\begin{array}{l}\text { Ada pihak ketiga sering } \\
\text { mengganggu menjalankan tugas, } \\
\text { tetapi diabaikan. }\end{array}$ & $\begin{array}{c}(13) \\
17.3 \%\end{array}$ & $\begin{array}{c}(4) \\
5.3 \%\end{array}$ & $\begin{array}{c}(9) \\
12.0 \%\end{array}$ & $\begin{array}{c}(24) \\
32.0 \%\end{array}$ & $\begin{array}{c}(25) \\
33.3 \%\end{array}$ & $\begin{array}{c}(75) \\
100.0 \%\end{array}$ & 3.59 & 1.443 \\
\hline $\begin{array}{l}\text { Menolak rasuah dan rezeki } \\
\text { haram demi keluarga dan anak. }\end{array}$ & & & $\begin{array}{l}(2) \\
2.7 \%\end{array}$ & $\begin{array}{l}(12) \\
16.0 \%\end{array}$ & $\begin{array}{l}(61) \\
81.3 \%\end{array}$ & $\begin{array}{c}(75) \\
100.0 \%\end{array}$ & 4.79 & .473 \\
\hline $\begin{array}{l}\text { Sentiasa menghubungi ketua jika } \\
\text { ada unsur menjejaskan integriti } \\
\text { sebagai penjawat awam. }\end{array}$ & & & $\begin{array}{l}(4) \\
5.3 \%\end{array}$ & $\begin{array}{c}(28) \\
37.3 \%\end{array}$ & $\begin{array}{c}(43) \\
57.3 \%\end{array}$ & $\begin{array}{c}(75) \\
100.0 \%\end{array}$ & 4.52 & .601 \\
\hline $\begin{array}{l}\text { Banyak gangguan dan masalah } \\
\text { peribadi menyebabkan kurang } \\
\text { tumpuan semasa bertugas. }\end{array}$ & $\begin{array}{c}(17) \\
22.7 \%\end{array}$ & $\begin{array}{l}(11) \\
14.7 \%\end{array}$ & $\begin{array}{c}(10) \\
13.3 \%\end{array}$ & $\begin{array}{c}(17) \\
22.7 \%\end{array}$ & $\begin{array}{c}(20) \\
26.7 \%\end{array}$ & $\begin{array}{c}(75) \\
100.0 \%\end{array}$ & 3.16 & 1.534 \\
\hline $\begin{array}{l}\text { Sangat percaya bahawa kerja } \\
\text { dilakukan adalah amanah selain } \\
\text { ibadah kepada Allah. }\end{array}$ & & $\begin{array}{l}(1) \\
1.3 \%\end{array}$ & $\begin{array}{l}(1) \\
1.3 \%\end{array}$ & $\begin{array}{c}(13) \\
17.3 \%\end{array}$ & $\begin{array}{c}(60) \\
80.0 \%\end{array}$ & $\begin{array}{c}(75) \\
100.0 \%\end{array}$ & 4.76 & .541 \\
\hline $\begin{array}{l}\text { Rakan setugas sering memberi } \\
\text { bimbingan dan bantuan sewaktu } \\
\text { menyelesaikan tugasan. }\end{array}$ & & & $\begin{array}{c}(4) \\
5.3 \%\end{array}$ & $\begin{array}{c}(26) \\
34.7 \%\end{array}$ & $\begin{array}{l}(45) \\
60.0 \%\end{array}$ & $\begin{array}{c}(75) \\
100.0 \%\end{array}$ & 4.55 & .599 \\
\hline $\begin{array}{l}\text { Sanggup kehilangan peluang } \\
\text { kenaikan pangkat demi integriti } \\
\text { dan imej pasukan PDRM. }\end{array}$ & $\begin{array}{c}(2) \\
2.7 \%\end{array}$ & $\begin{array}{l}(1) \\
1.3 \%\end{array}$ & $\begin{array}{c}(9) \\
12.0 \%\end{array}$ & $\begin{array}{l}(31) \\
41.3 \%\end{array}$ & $\begin{array}{c}(32) \\
42.7 \%\end{array}$ & $\begin{array}{c}(75) \\
100.0 \%\end{array}$ & 4.20 & .900 \\
\hline $\begin{array}{l}\text { Sanggup melaporkan rasuah dan } \\
\text { penyelewengan dalam PDRM } \\
\text { kepada pihak atasan. }\end{array}$ & & $\begin{array}{l}(1) \\
1.3 \%\end{array}$ & $\begin{array}{c}(8) \\
10.7 \%\end{array}$ & $\begin{array}{c}(29) \\
38.7 \%\end{array}$ & $\begin{array}{c}(37) \\
49.3 \%\end{array}$ & $\begin{array}{c}(75) \\
100.0 \%\end{array}$ & 4.36 & .729 \\
\hline $\begin{array}{l}\text { Menjaga integriti pasukan adalah } \\
\text { suatu kewajipan dan amanah. }\end{array}$ & & & $\begin{array}{l}(1) \\
1.3 \%\end{array}$ & $\begin{array}{c}(19) \\
25.3 \%\end{array}$ & $\begin{array}{c}(55) \\
73.3 \%\end{array}$ & $\begin{array}{c}(75) \\
100.0 \%\end{array}$ & 4.72 & .481 \\
\hline $\begin{array}{l}\text { Sedia dihantar ke kursus } \\
\text { pemantapan jiwa dan sahsiah } \\
\text { demi mendukung nilai integriti. }\end{array}$ & & & $\begin{array}{c}(8) \\
10.7 \%\end{array}$ & $\begin{array}{c}(28) \\
37.3 \%\end{array}$ & $\begin{array}{c}(39) \\
52.0 \%\end{array}$ & $\begin{array}{c}(75) \\
100.0 \%\end{array}$ & 4.41 & .680 \\
\hline $\begin{array}{l}\text { Imej pasukan PDRM tercalar } \\
\text { akibat salah laku segelintir } \\
\text { pegawai dan anggota tidak } \\
\text { berintegriti. }\end{array}$ & & & $\begin{array}{c}(2) \\
2.7 \%\end{array}$ & $\begin{array}{c}(19) \\
25.3 \%\end{array}$ & $\begin{array}{c}(54) \\
72.0 \%\end{array}$ & $\begin{array}{c}(75) \\
100.0 \%\end{array}$ & 4.69 & .519 \\
\hline
\end{tabular}

Pada asasnya, responden memahami maksud integriti (min 4.45) dan yakin bahawa dirinya adalah seorang yang berintegriti (min 4.44). Justeru, mereka sentiasa melakukan tugas mengikut SOP, etika kerja dan manual yang telah dilancarkan oleh pasukan PDRM (min 4.40). Apabila nilai-nilai itu menjadi prinsip dalam bertugas, maka pegawai dan anggota terbabit tidak pernah bertolak ansur terhadap perbuatan yang melanggar etika kerja dan undang-undang (min 4.00). Semua penilaian bersetuju dan sangat bersetuju bagi keempat-empat item ini adalah 90 peratus ke atas.

Walau bagaimanapun, sewaktu menjalankan tugas, terdapat cabaran dan dugaan serta gangguan daripada pihak ketiga hingga cenderung melakukan kesalahan dan penyelewengan. Dalam isu pernah diberi teguran lisan, sebanyak 45.3 peratus (bersetuju dan sangat bersetuju) pernah mengalami saat tersebut, namun berusaha memperbaiki kesilapan lalu demi imej pasukan PDRM dengan nilai min 4.49 dan 96 peratus (bersetuju dan sangat bersetuju) dalam perkara ini. Justeru, bagi mengelak kesilapan semasa bertugas, maka pegawai dan anggota perlu memberi 100 peratus tumpuan (min 4.63) agar tidak berlaku kesilapan dan kecuaian, di mana 97.3 peratus (bersetuju dan sangat bersetuju) mengenai 
perkara ini. Namun, dalam melaksanakan tugas, terdapat gangguan daripada pihak ketiga terutama untuk memberi rasuah ( $\min 4.52$ ), tetapi menolaknya ( $\min 4.79$ ) adalah tertinggi dan menghubungi ketua bagi memaklumkan perkara tersebut (min 4.52). Selain itu, pegawai dan anggota PDRM juga berhadapan dengan banyak gangguan lain dan juga masalah peribadi yang menyebabkan kurang tumpuan semasa melakukan tugasan (min 3.16), di mana penilaian bersetuju dan tidak bersetuju adalah 49.4 peratus sahaja.

Selain itu, 97.3 peratus responden percaya bahawa kerja yang dilakukan adalah amanah dan suatu ibadah kepada Allah swt (nilai min 4.76). Justeru, rakan setugas sering memberi bimbang dan bantuan sewaktu melakukan tugas agar tidak terjebak dalam perkara yang tidak diingini (min 4.55), di mana 94.7 peratus menilai bersetuju dan sangat bersetuju dengan perkara ini. Demi integriti dan imej pasukan PDRM, 84 peratus responden bersetuju dan sangat bersetuju, di mana sanggup kehilangan peluang kenaikan pangkat jika tindakannya melaporkan rasuah dan penyelewengan dalam PDRM kepada pihak atasan. Matlamat ini dilakukan kerana beranggapan menjaga integriti PDRM adalah suatu kewajipan dan amanah (min 4.72), di mana 98.6 peratus (bersetuju dan sangat bersetuju) mengenai nilai ini. Atas sebab itu, responden mengakui imej pasukan PDRM tercalar akibat salah laku segelintir pegawai dan anggotanya (min 4.69) ibarat akibat nila setitik, rosak susu sebelanga. Oleh sebab itu, responden sanggup dihantar mengikuti kursus pemantapan jiwa dan sahsiah demi mendukung nilai integriti (min 4.41) (89.3 peratus bersetuju dan sangat bersetuju).

Dalam pada itu, responden turut ditanya mengenai kesedaran dan kepekaan terhadap isu perlanggaran integriti dan akauntabiliti yang boleh menyebabkan imej dan kredibiliti PDRM dipertikaikan oleh masyarakat. Jadi, pelanggaran terhadap kod etika dan dasar integriti dalam PDRM perlu dilaporkan segera (min 4.44), di mana 90.6 peratus responden (bersetuju dan sangat bersetuju) berkenaan perkara ini seperti ditunjukkan dalam Jadual 17. Dalam pada itu, sebanyak 61.3 peratus pernah melaporkan secara rasmi pelanggaran itu kepada pihak atasan (min 3.65). Sebaliknya, ada yang tahu mengenai pelanggaran itu, tetapi tidak ambil peduli dan mengabaikannya (36.5 peratus) dengan nilai min 2.72 . Justeru, pegawai dan anggota PDRM mesti tahu mekanisme untuk melaporkan pelanggaran etika kerja dan integriti (74.3 peratus dan nilai min 4.00). Mereka tidak melaporkan pelanggaran itu sebab bimbang identiti tidak dirahsiakan ( $\min 3.20$ dan 50 peratus bersetuju dan sangat bersetuju).

Jadual 17: Pengawasan Pelanggaran Integriti Demi Akauntabiliti

\begin{tabular}{|c|c|c|c|c|c|c|c|c|}
\hline \multirow{2}{*}{ Item Diukur } & \multicolumn{5}{|c|}{ Penilaian } & \multirow{2}{*}{$\begin{array}{l}\text { Total } \\
100 \%\end{array}$} & \multirow{2}{*}{ Min } & \multirow{2}{*}{$\begin{array}{c}\text { Sisihan } \\
\text { Piawai }\end{array}$} \\
\hline & 1 & 2 & 3 & 4 & 5 & & & \\
\hline $\begin{array}{l}\text { Pelanggaran atau } \\
\text { ketidakpatuhan kepada kod } \\
\text { etika dan dasar integriti perlu } \\
\text { dilaporkan segera. }\end{array}$ & & & $\begin{array}{c}(7) \\
9.3 \%\end{array}$ & $\begin{array}{c}(28) \\
37.3 \%\end{array}$ & $\begin{array}{c}(40) \\
53.3 \%\end{array}$ & $\begin{array}{c}(75) \\
100.0 \%\end{array}$ & 4.44 & .663 \\
\hline $\begin{array}{l}\text { Anda kerap melaporkan } \\
\text { pelanggaran dan } \\
\text { ketidakpatuhan secara rasmi } \\
\text { kepada pegawai yang } \\
\text { berkenaan. }\end{array}$ & $\begin{array}{c}(3) \\
4.0 \%\end{array}$ & $\begin{array}{c}(6) \\
8.0 \%\end{array}$ & $\begin{array}{c}(20) \\
26.7 \%\end{array}$ & $\begin{array}{c}(31) \\
41.3 \%\end{array}$ & $\begin{array}{c}(15) \\
20.0 \%\end{array}$ & $\begin{array}{c}(75) \\
100.0 \%\end{array}$ & 3.65 & 1.020 \\
\hline $\begin{array}{l}\text { Walaupun tahu ada } \\
\text { pelanggaran dan } \\
\text { ketidakpatuhan, anda tidak } \\
\text { ambil peduli dan abaikannya. }\end{array}$ & $\begin{array}{c}(24) \\
32.4 \%\end{array}$ & $\begin{array}{c}(12) \\
16.2 \%\end{array}$ & $\begin{array}{c}(11) \\
14.9 \%\end{array}$ & $\begin{array}{c}(15) \\
20.3 \%\end{array}$ & $\begin{array}{c}(12) \\
16.2 \%\end{array}$ & $\begin{array}{c}(74) \\
100.0 \%\end{array}$ & 2.72 & 1.504 \\
\hline $\begin{array}{l}\text { Anda tahu ada mekanisme } \\
\text { dalaman bagi mengendalikan } \\
\text { dan melaporkan pelanggaran } \\
\text { kod etika dan integriti. }\end{array}$ & $\begin{array}{c}(1) \\
1.4 \%\end{array}$ & $\begin{array}{c}(2) \\
2.7 \%\end{array}$ & $\begin{array}{c}(16) \\
21.6 \%\end{array}$ & $\begin{array}{c}(32) \\
43.2 \%\end{array}$ & $\begin{array}{c}(23) \\
31.1 \%\end{array}$ & $\begin{array}{c}(74) \\
100.0 \%\end{array}$ & 4.00 & .876 \\
\hline $\begin{array}{l}\text { Tidak melaporkan } \\
\text { pelanggaran kod etika dan } \\
\text { integriti disebabkan bimbang } \\
\text { identiti tidak dirahsiakan. }\end{array}$ & $\begin{array}{c}(13) \\
17.6 \%\end{array}$ & $\begin{array}{c}(10) \\
13.5 \%\end{array}$ & $\begin{array}{c}(14) \\
18.9 \%\end{array}$ & $\begin{array}{c}(23) \\
31.1 \%\end{array}$ & $\begin{array}{c}(14) \\
18.9 \%\end{array}$ & $\begin{array}{c}(74) \\
100.0 \%\end{array}$ & 3.20 & 1.375 \\
\hline
\end{tabular}



DOI: https://doi.org/10.47405/mjssh.v6i9.1024

Melindungi kerahsiaan

identiti pelapor perlu untuk

menegakkan integriti dan

(4) (33)

$5.4 \%$

(37)

(74)

akauntabiliti awam PDRM.

4.45

.600

Lanjutan daripada isu dibincangkan di atas, sebanyak $66.2 \%$ responden (bersetuju dan sangat bersetuju) bahawa prosedur untuk melaporkan pelanggaran kod etika dan integriti sebenar tidak jelas dalam PDRM dan tidak dinyatakan secara bertulis (min 3.74) seperti ditunjukkan dalam Jadual 18. Justeru, PDRM disarankan agar mengkaji semula dan memperbaharui dasar dan amalan integriti dan kod etika perkhidmatan bagi meningkatkan akauntabiliti awam dan memerangi rasuah (penilaian 89.2 peratus bersetuju dan sangat bersetuju, nilai min 4.38). Dalam masa yang sama, difahami pelanggaran itu tidak dilakukan siasatan secara terperinci dan sistematik (min 4.19), di mana 78.6 peratus responden mengakui perkara ini.

Jadual 18: Prosedur Pelaporan Pelanggaran Integriti Demi Akauntabiliti

\begin{tabular}{|c|c|c|c|c|c|c|c|c|}
\hline \multirow{2}{*}{ Item Diukur } & \multicolumn{5}{|c|}{ Penilaian } & \multirow{2}{*}{$\begin{array}{l}\text { Total } \\
100 \%\end{array}$} & \multirow{2}{*}{ Min } & \multirow{2}{*}{$\begin{array}{c}\text { Sisihan } \\
\text { Piawai }\end{array}$} \\
\hline & 1 & 2 & 3 & 4 & 5 & & & \\
\hline $\begin{array}{l}\text { Prosedur untuk melaporkan } \\
\text { pelanggaran kod etika dan } \\
\text { integriti ke arah pembentukan } \\
\text { akauntabiliti awam tidak jelas } \\
\text { dalam PDRM dan tidak } \\
\text { dinyatakan secara bertulis. }\end{array}$ & $\begin{array}{c}(6) \\
8.1 \%\end{array}$ & $\begin{array}{c}(2) \\
2.7 \%\end{array}$ & $\begin{array}{c}(17) \\
23.0 \%\end{array}$ & $\begin{array}{c}(29) \\
39.2 \%\end{array}$ & $\begin{array}{c}(20) \\
27.0 \%\end{array}$ & $\begin{array}{c}(74) \\
100.0 \%\end{array}$ & 3.74 & 1.135 \\
\hline $\begin{array}{l}\text { PDRM perlu mengkaji semula } \\
\text { dan memperbaharui dasar dan } \\
\text { amalan integriti dan kod etika } \\
\text { perkhidmatan bagi meningkatkan } \\
\text { akauntabilit awam dan } \\
\text { memerangi rasuah. }\end{array}$ & & $\begin{array}{c}(2) \\
2.7 \%\end{array}$ & $\begin{array}{c}(6) \\
8.1 \%\end{array}$ & $\begin{array}{c}(28) \\
37.8 \%\end{array}$ & $\begin{array}{c}(38) \\
51.4 \%\end{array}$ & $\begin{array}{c}(74) \\
100.0 \%\end{array}$ & 4.38 & .753 \\
\hline $\begin{array}{l}\text { Siasatan ke atas pelanggaran kod } \\
\text { etika dan integriti tidak } \\
\text { dilakukan secara terperinci dan } \\
\text { sistematik kerana lebih bersifat } \\
\text { acuh tidak acuh. }\end{array}$ & $\begin{array}{c}(8) \\
10.8 \%\end{array}$ & $\begin{array}{c}(5) \\
6.8 \%\end{array}$ & $\begin{array}{c}(15) \\
20.3 \%\end{array}$ & $\begin{array}{c}(23) \\
31.1 \%\end{array}$ & $\begin{array}{c}(23) \\
31.1 \%\end{array}$ & $\begin{array}{c}(74) \\
100.0 \%\end{array}$ & 3.65 & 1.287 \\
\hline $\begin{array}{l}\text { PDRM mempunyai dasar bertulis } \\
\text { yang mengatur pelantikan, } \\
\text { pengurusan dan badan penasihat } \\
\text { bagi mengawasi amalan rasuah. }\end{array}$ & & $\begin{array}{c}(1) \\
1.3 \%\end{array}$ & $\begin{array}{c}(15) \\
20.0 \%\end{array}$ & $\begin{array}{c}(28) \\
37.3 \%\end{array}$ & $\begin{array}{c}(31) \\
41.3 \%\end{array}$ & $\begin{array}{c}(75) \\
100.0 \%\end{array}$ & 4.19 & .800 \\
\hline $\begin{array}{l}\text { Rakan setugas sebenarnya patut } \\
\text { menjadi pelapor kepada } \\
\text { pelanggaran kod etika dan } \\
\text { integriti untuk membendung } \\
\text { penyalahgunaan kuasa dan } \\
\text { rasuah. }\end{array}$ & $\begin{array}{c}(1) \\
1.3 \%\end{array}$ & $\begin{array}{c}(1) \\
1.3 \%\end{array}$ & $\begin{array}{c}(12) \\
16.0 \%\end{array}$ & $\begin{array}{c}(31) \\
41.3 \%\end{array}$ & $\begin{array}{c}(30) \\
40.0 \%\end{array}$ & $\begin{array}{c}(75) \\
100.0 \%\end{array}$ & 4.17 & .844 \\
\hline $\begin{array}{l}\text { PDRM perlu mewujudkan badan } \\
\text { khas bagi menyiasat pelanggaran } \\
\text { kod etika dan integriti bagi } \\
\text { mengelak imej dan kredibiliti } \\
\text { pasukan tercalar. }\end{array}$ & $\begin{array}{c}(6) \\
8.0 \%\end{array}$ & $\begin{array}{c}(6) \\
8.0 \%\end{array}$ & $\begin{array}{c}(7) \\
9.3 \%\end{array}$ & $\begin{array}{c}(21) \\
28.0 \%\end{array}$ & $\begin{array}{c}(35) \\
46.7 \%\end{array}$ & $\begin{array}{c}(75) \\
100.0 \%\end{array}$ & 3.97 & 1.273 \\
\hline $\begin{array}{l}\text { PDRM menyerah sepenuhnya } \\
(100 \%) \text { hal ehwal penyiasatan } \\
\text { berkaitan pelanggaran kod etika } \\
\text { dan gelaja rasuah dalam pasukan } \\
\text { kepada SPRM. }\end{array}$ & $\begin{array}{c}(19) \\
25.3 \%\end{array}$ & $\begin{array}{c}(12) \\
16.0 \%\end{array}$ & $\begin{array}{c}(9) \\
12.0 \%\end{array}$ & $\begin{array}{c}(17) \\
22.7 \%\end{array}$ & $\begin{array}{c}(18) \\
24.0 \%\end{array}$ & $\begin{array}{c}(75) \\
100.0 \%\end{array}$ & 3.04 & 1.546 \\
\hline
\end{tabular}


Atas sebab itu, ada saranan agar rakan setugas (min 4.17) sebenarnya patut menjadi pelapor kepada pelanggaran kod etika dan integriti untuk membendung penyalahgunaan kuasa dan rasuah (81.3 peratus bersetuju dan sangat bersetuju). Oleh itu, berhubung perkara ini, maka disarankan PDRM mempunyai dasar bertulis untuk mengatur pelantikan, pengurusan dan badan penasihat bagi mengawasi amalan rasuah (min 4.19). Di samping itu, PDRM perlu mewujudkan badan khas bagi menyiasat pelanggaran kod etika dan integriti bagi mengelak imej dan kredibiliti pasukan tercalar (nilai min 3.97). Dalam hal ini, sebanyak 46.7 peratus sahaja responden yang bersetuju dan sangat bersetuju agar PDRM menyerah sepenuhnya (100 peratus) hal ehwal penyiasatan berkaitan pelanggaran kod etika dan gelaja rasuah dalam pasukan kepada SPRM.

\section{Kesimpulan}

Secara umumnya, PDRM telah mempunyai dasar dan strategi yang jelas ke arah pengukuhan pemantapan integriti dalam menyampaikan perkhidmatan kepolisan di Malaysia. Dasar dan strategi yang telah dilaksanakan itu perlu diperkukuhkan dan dilaksanakan secara sistematik melalui mekanisme tadbir urus yang baik agar sistem perkhidmatan kepolisan itu terus mendapat kepercayaan dalam kalangan rakyat. Justeru, pegawai dan anggota PDRM perlu memiliki kesedaran dan komitmen yang tinggi ke arah menegakkan integriti dalam menyampaikan perkhidmatan kepolisan kepada masyarakat.

Tanpa kesedaran dan komitmen yang tinggi, integriti tidak boleh dihasilkan dalam organisasi polis di Malaysia kerana nilai ini banyak dipengaruhi oleh faktor komitmen, mentaliti, tingkah laku dan keperibadian individu. Oleh itu, usaha meningkatkan kesedaran tentang integriti mesti dilakukan melalui banyak cara termasuklah menghadiri kursus jangka pendek, latihan dalaman dan pemerhatian oleh pihak atasan secara berterusan. Paling penting perbuatan mencemarkan integriti seperti menerima rasuah bukan sahaja dikaitkan dengan pelanggaran undang-undang, tetapi juga melanggar hukum agama.

Jadi, kajian kesedaran tentang integriti melibatkan pegawai dan anggota PDRM di Ibu Pejabat Kontigen Ipoh bertujuan meninjau sejauh mana mereka memahami kepentingan integriti itu. Dalam menyampaikan perkhidmatan kepolisan kepada masyarakat, mereka menghadapi banyak cabaran yang cenderung ke arah kemerosotan nilai integriti. Perkara ini dibimbangi oleh pengurusan atasan PDRM dan kerajaan kerana tindakan bertentangan dengan integriti pasti memberikan nama buruk kepada organisasi. Analisis dapatan kajian menunjukkan bahawa kesedaran pegawai dan anggota PDRM tentang keperluan nilai integriti di Perak berada di tahap yang memuaskan.

Penilaian ini secara signifikannya ada kaitan dengan ajaran yang dianuti, di mana 90.7 peratus responden adalah beragama Islam. Sebagai seorang Muslim, responden perlu memahami konsep dosa dan pahala dalam Islam. Justeru, jika mereka menerima rasuah, bermakna mereka telah melakukan dosa dan sekali gus melanggari undang-undang. Apabila pegawai dan anggota PDRM berpegang kepada prinsip dosa dan pahala dalam melaksanakan tugas dan menyampaikan perkhidmatan, mereka pasti dapat mengelak daripada melakukan pelanggaran kepada nilai integriti. Justeru, mereka perlu jujur, ikhlas, amanah dan bertanggungjawab dalam melaksanakan tanggungjawab yang telah diamanahkan.

Dapatan kajian ini mempunyai persamaan dengan dapatan kajian oleh Hanafi (2014) yang mengkaji integriti berlandaskan nilai Islam adalah kaedah terbaik dalam menyampaikan perkhidmatan. Ringkasnya integriti mempunyai hubungan rapat dengan konsep ketuhanan, di mana setiap perkara baik yang dilakukan akan dibalas kebaikan dan sebaliknya. Oleh itu, pegawai dan kakitangan PDRM mesti melakukan perkara baik dan mengelak perkara jahat. Berasaskan konsep ini, ia boleh menjadi pendorong ke arah pengukuhan integriti dalam melaksanakan tugas.

Dapatan kajian ini turut menunjukkan pelbagai jawatan disandang oleh responden. Melalui jawatanjawatan tersebut khususnya pegawai atas, mereka boleh menjadi role model dalam PDRM itu sendiri khususnya kepada pegawai bawahan dan anggota-anggota lain. Sebagai role model, mereka perlu 
menunjukkan teladan yang baik berteraskan integriti dalam melakukan tugasan masing-masing. Ini menepati apa yang dirumuskan oleh Megat Ayop dan Abd. Halim (2016a; 2016b) yang menjelaskan budaya kerja berteraskan integriti adalah tunjang persepsi positif rakyat kepada PDRM. Dengan kata lain, PDRM boleh menjadi role model kepada rakyat untuk mengutamakan integriti dalam semua aktiviti yang dilakukan menerusi sikap yang berdisiplin, berakhlak baik, melakukan kerja dengan teliti dan menolak rasuah.

Dapatan kajian mendapati sebahagian besar responden pernah mendapat Anugerah Perkhidmatan Cemerlang yang sebagai petunjuk bahawa mereka telah membuktikan kecemerlangan sewaktu melakukan tugas yang diberikan. Kecemerlangan itu tidak hanya dalam menyampaikan perkhidmatan kepolisan, tetapi turut bergerak aktif dalam aktiviti kesukarelaan, kemasyarakatan, sukan dan kebudayaan. Justeru, responden berupaya boleh memberi pelbagai sumbangan lain kepada masyarakat dan negara. Seterusnya anugerah perkhidmatan cemerlang yang diterima itu boleh menjadi pendorong meningkatkan semangat bekerja dengan lebih tekun. Perkara ini menepati penemuan daripada kajian oleh $\mathrm{Ng}$ (1999), di mana motivasi kerja pegawai polis banyak dipengaruhi oleh faktor pengiktirafan dan anugerah yang diterima sebagai pendorong untuk bekerja dengan lebih bersemangat, tekun dan berdisiplin.

Selain itu, keutuhan nilai dalam diri responden itu amat penting dalam usaha mengukuhkan integriti dalam PDRM. Atas sebab itu PDRM mempunyai agenda khusus dalam memperkasa sumber manusia dan hala gerak kerja organisasi keselamatan utama di Malaysia ini. Dapatan kajian menunjukkan bahawa responden mempunyai kesedaran tinggi dalam perkara ini dalam menyampaikan perkhidmatan kepolisan secara berkesan di Malaysia demi ketenteraman dan kesejahteraan rakyat. Dapatan ini mempunyai persamaan dengan kajian oleh Lee dan Nur Hairani (2019) yang menyifatkan integriti adalah nilai yang berupaya menjadikan polis berjaya menjalankan tugas dengan baik dalam membenteras dan menyelesaikan kes-kes jenayah di Malaysia. Dengan pencapaian itu, integriti memberi kesan dan imej positif kepada pasukan PDRM di mata rakyat.

Untuk meningkatkan integriti dan akauntabiliti dalam PDRM, tiga buku iaitu Kod Etika PDRM, Pelan Integriti PDRM 2016-2020 dan Manual Pematuhan Standard telah diterbitkan. Dapatan kajian ini mendapati responden memahami dan mengetahui secara jelas tujuan dan keperluan semua buku itu. Atas sebab itu, pegawai dan anggota PDRM mesti memahami secara terperinci dasar dan prosedur yang perlu dipatuhi dalam melaksanakan tugas tugasan masing-masing. Misalnya, Megat Ayop dan Abd. Halim (2016b) menyifatkan Kod Etika PDRM boleh dijadikan sebagai peraturan rasmi yang menekankan peri penting amalan integriti dalam menjalankan tugas. Sementara itu, Mohd Koharuddin et al. (2012) menjelaskan penjawat awam termasuk pegawai dan anggota PDRM perlu memberi fokus kepada etika baik berdasarkan kepada peraturan-peraturan yang dikuatkuasakan dalam melaksanakan tugas mereka. Jadi, pengenalan tiga buku panduan adalah pembaharuan dalam PDRM ke arah pengukuhan integriti dan akauntabiliti.

Dalam pada itu, sumber-sumber lina seperti Pekeliling Perkhidmatan; Perintah Tetap Ketua Polis Negara; Standard Operating Procedure; Arahan-Arahan Pentadbiran; ISO 9001:2008; Manual Prosedur Kerja; dan Pembahagian Kerja yang dikeluarkan untuk meningkatkan nilai integriti dan akauntabiliti dalam organisasi PDRM. Dapatan kajian menunjukkan majoriti responden memahami dengan baik keperluan sumber-sumber ini dalam PDRM. Perkara ini mempunyai persamaan dengan penemuan kajian oleh Walker (2007), di mana akauntabiliti adalah perkara penting untuk menyampaikan perkhidmatan kepolisan yang berkesan polis untuk mencapai matlamatnya.

Hakikatnya, pegawai dan anggota PDRM sentiasa berhadapan situasi sangat mencabar sewaktu melaksanakan tugas mereka. Mereka sering berada dalam dilema apabila ada pihak ketiga yang kerap mengganggu sewaktu mereka menjalankan tugas. Isu ini pernah dibahaskan oleh Parliament of Victoria (2018: xv) seperti "police play a critical role in society, preventing and combating crime, enforcing the law and protecting, assisting and engaging with the community in a myraid of way. The job of a police officer is demanding one: they can be called on to make split-second decisions in complex, stressful and dangerous circumstances". Di Malaysia, jika perkara ini gagal ditangani, ia boleh menyebabkan tanggungjawab polis itu menjadi sangat mencabar sebagai pasukan barisan 
hadapan yang menjaga kedaulatan negara. Jadi, mereka mesti menjaga dan mengekalkan nama baik PDRM di mata rakyat ke arah tadbir urus yang baik. Jadi, kepercayaan rakyat kepada polis menurut Armstrong (2005) adalah kunci tadbir urus yang baik.

\section{Rujukan}

Armstrong, E. (2005). Integrity, transparency and accountability in public administration: Recent trends, regional and international developments and emerging issues. Economic \& Social Affairs, United Nations. (August). Retrieved from https://www.insightsonindia.com/....integritytransparency-un.pdf. (01 Mei 2020).

Berita Harian. (22 Mac, 2008). 'Tegas, Adil, Berhemah' slogan PDRM.

Bogdan, R., \& Biklen, S.K. (1998). Qualitative research for education: An introduction to theories and methods. Boston: Allyn and Bacon.

Charter, S.L., (1996). Integrity. New York: Basic Books.

Che Ghazali, C.A. (2011). Faktor-faktor yang mempengaruhi sikap kakitangan terhadap perubahan organisasi: Satu kajian ke atas Polis Diraja Malaysia. Disertasi Doktor Pentadbiran Perniagaan, Universiti Utara Malaysia (Tidak diterbitkan).

Creswell, J.W., \& Clark, V.L.P. (2007). Designing and conducting mixed methods research. New York: SAGE.

Diamond, C. (2001). Integrity (pp. 863-866). Dlm. L.C. Becker \& C.B. Becker (Eds.). Encyclopedia of Ethic, 2(3). New York: Routledge.

Fraenkel, J.R., \& Wallen, N.E. (2007). How to design and evaluate research in education. (6th Ed.). New York: McGraw-Hill.

Hanafi, H. (2014). Integriti menurut hadith Nabi: Kajian terhadap kefahaman kakitangan pentadbiran UiTM Shah Alam. Tesis Sarjana, Universiti Malaya (Tidak diterbitkan).

Heywood, P., Marquette, H., Peiffer, C., \& Zuniga, N. (2017). Integrity and integrity management in public life. European Union. Retrieved from http://anticorrp.eu/publications/....integritymanagement-in-public-life. (01 Mei 2020).

Huberts, L.W.J.C. (2014). The integrity of governance. What it is, what we know, what is done, and where to go. Basingstoke, England: Palgrave Macmillan.

Institut Integriti Malaysia. (2016). Laporan Tahunan. Kuala Lumpur: Institut Integriti Malaysia.

Jamiah, M., et. al. (2007). Pemantapan nilai integriti individu sebagai teras pembangunan staf berkualiti. Jurnal Akademik. (02 Januari 2016).

Khalid, A.B. (13 Ogos 2016). Memperkasakan PDRM. Harian Metro.

Lee, K.H., \& Nur Hairani, A.R. (2019). Persepsi masyarakat terhadap kualiti perkhidmatan Polis Diraja Malaysia. Jurnal Dunia Pengurusan, 1(3), 23-29.

Lee-Jones, K. (2018). Best practices in addressing police-related corruption. Anti-Corruption Resource Centre, Transparency International. Retrieved from https://www.u4.no/..../bestpractices-in-addressing-police-related-corruption.pdf. (01 Mei 2020).

Loganathan, S. (2012). Hubungan antara gaya kepimpinan dengan komitmen organisasi di Ibu Pejabat Polis Daerah Kluang, Johor. Projek Sarjana, Universiti Teknologi Malaysia (Tidak diterbitkan).

Luqman Arif, A.K. (7 Mei 2019). IPCMC untuk kukuhkan institusi polis. Berita Harian.

Madzainin, R., Mohd Nasir, M., \& Mastura, M. (2017). Kecerdasan Emosi Dalam Kalangan Anggota Polis Di Jabatan Siasatan Jenayah IPD Iskandar Puteri. Seminar Kelastarian Perkhidmatan Awam 2017.

Mazilan, M., Izal Arif, Z., \& Suzanna, C.M. (Eds.). (2005). Etika dan integriti di Malaysia: Isu dan cabaran. Kuala Lumpur: Institut Integriti Malaysia.

McFall, L. (1987). Integrity. Ethics, 98(1), 5-20.

Megat Ayop, M.A., \& Abd. Halim, A. (2016a). Kepentingan budaya integriti dan etika kerja dalam organisasi di Malaysia: Suatu tinjauan umum. Malaysian Journal of Society and Space, 12(9), 138-149.

Megat Ayop, M.A., \& Abd. Halim, A. (2016b). Konsep integriti dalam organisasi Polis Diraja Malaysia (PDRM): Satu tinjauan awal. Malaysian Journal of Society and Space, 12(8), 135-147.

Menzel, D.C. (2005). Research on ethics and integrity in governance: A review and assessment. Public Integrity, 7(2), 147-168. 
Mohd Koharuddin, M.B., Rosman, M.Y., Mohd Azhar, A.H., Muhammad Fauzi, O., \& Nasir, M. (2012). Etika kerja dalam kalangan penjawat awam Malaysia: Perbincangan makro dan mikro ke atas pembuatan keputusan. Jurnal Teknologi, 58, 57-62.

Mohd. Mahiri, H. (2020). Integriti dan akauntabiliti awam: Analisis peranan pegawai dan anggota PDRM). Projek Sarjana Fakulti Pengurusan dan Teknologi Maklumat, Universiti Sultan Azlan Shah, Perak (Tidak diterbitkan).

Mohd. Majid, K. (1998). Kaedah penyelidikan pendidikan. Kuala Lumpur: Dewan Bahasa dan Pustaka.

Mohd Ngaizuddin, A.M. (2014). Kepuasan pelanggan terhadap perkhidmatan kaunter pejabat pertanyaan Balai Polis Pengkalan Hulu, Perak. Tesis Sarjana Pengurusan, Universiti Utara Malaysia (Tidak diterbitkan).

Montefiore, A. (1999). Integrity: A philosopher's introduction. Dlm. Alan Montefiore \& David Vines (Eds.). Integrity in the public and private domains. London: Routledge.

Muhammad Aidil, R.A. (2011). Amalan kerja beretika dalam Polis Diraja Malaysia: Satu kajian di Ibu Pejabat Polis Daerah Kulaijaya, Johor. Tesis Sarjana, Universiti Sains Malaysia (Tidak diterbitkan).

Muzaffar, S.M. (29 Jun 2016). Budaya integriti penjawat awam. Utusan Malaysia.

Ng, C.T. (1999). Persepsi motivasi kerja pegawai polis di negeri Melaka: Perbandingan antara Inspektor dengan anggota pangkat rendah. Projek Sarjana Sains (Pembangunan Sumber Manusia), Universiti Putra Malaysia (Tidak diterbitkan).

Nursyazlin, Y.M.Z., \& Noraini, A.R. (2017). Faktor-faktor yang mempengaruhi tekanan kerja dalam kalangan anggota polis: Satu kajian di kem batalion 9 PGA Kuala Terengganu. Malaysian Journal of Social Science, 2, 103-116.

Parliament of Victoria. (2018). Inquiry into the external oversight of police corruption and misconduct in Victoria. Australia: Independent Broad-based Anti-corruption Commission Committee, Parliament of Victoria.

Pyo, C. (2008). Background Report: Examining Existing Police Oversight Mechanisms in Asia. Presented at the workshop improving the Role of the Police in Asia and Europe, 3-4 December 2008. Asia-Europe Foundation and University of Delhi. Retrieved from https://www.asef.org/....oversight Mechanisms in Asia.pdf. (01 Mei 2020).

United Nations Office on Drugs and Crime (UNODC). (2011). Handbook on police accountability, oversight and integrity. Criminal Justice Handbook Series. New York: United Nations.

Walker, S. (2007). Police accountability: Current issues and research needs. Paper presented at the National Institute of Justice (NIJ) Policing Research Workshop: Planning for the Future, Washington, DC, 28-29 November 2006. 